Tomasz Ciesielski (Opole)

\title{
Pióra w służbie buławy. O kancelariach i archiwaliach hetmańskich w XVIII w.
}

\section{WPROWADZENIE}

W badaniach nie tylko historyczno-wojskowych, ale też nad dziejami politycznymi, kulturalnymi, gospodarczymi, a nawet społecznymi Rzeczypospolitej Obojga Narodów w XVIII w. historycy, historycy prawa, historycy sztuki czy literatury bardzo często i chętnie sięgają do spuścizn po hetmanach. Spowodowane to jest przede wszystkim znaczeniem, jakie odgrywały w państwie osoby dzierżące buławy (nie tylko hetmańskie, ale też i regimentarzy generalnych), które były nie tylko dowódcami obu armii Rzeczypospolitej, ale też senatorami, przywódcami silnych fakcji magnacko-szlacheckich czy dużych stronnictw, pozostającymi przy tym przez większość czasu w opozycji do dworu królewskiego, z liczną klientelą zbudowaną między innymi w oparciu o władzę posiadaną $\mathrm{w}$ armii ${ }^{1}$. Byli też prominentnymi, jeżeli nie najważniejszymi osobami w swoich rodach, głowami rodzin, jak też właścicielami rozległych majątków ziemskich, zatrudniających liczne grono dworzan, urzędników, artystów (architektów, rzeźbiarzy, malarzy itp). Do prowadzenia wieloaspektowych badań nad dziedzictwem Rzeczypospolitej Obojga Narodów w oparciu o archiwalne i biblioteczne spuścizny hetmańskie skłaniają także rozmiary i rozbudowana tektonika części z nich, oparta o podział na materiały wojskowe, publiczne, gospodarczo-majątkowe, rodzinne i osobiste,

1 T. Ciesielski, Armia koronna w czasach Augusta III, Warszawa 2009, s. 134-137; idem, Działalność wojskowa hetmana wielkiego koronnego Józefa Potockiego i jego kręgu klientalno-rodzinnego, [w:]: J. Urwanowicz (red.), Magnateria Rzeczypospolitej w XVII-XVIII wieku, Białystok 2003, s. 259-282; idem, Michał Kazimierz Radziwitt jako dowódca armii litewskiej w latach 1735-1762, [w:] M. Nagielski, K. Żojdź (red.), Radziwiłtowie w służbie Marsa, Warszawa 2017, s. 299-311. 
a także priora. Do takich spuścizn zaliczyć należy archiwa Adama Mikołaja Sieniawskiego (zespolone z dokumentami i aktami wytworzonymi przez Czartoryskich), Jana Klemensa Branickiego, Rzewuskich i Radziwiłłów. W „podróżach badawczych" po ich zasobach sporą trudność historykom wojskowości sprawiać może prawidłowa selekcja i ocenienie materiałów archiwalnych, oddzielenie tego, co prywatne, od spraw publicznych, rozgraniczenie interesu własnego hetmana od służby państwowej i wykonywania obowiązków, do których zobowiązywał pełniony urząd. Powodów tego jest kilka. Pierwszy z nich to trudności z prawidłowym określeniem zakresu władzy hetmańskiej, wynikającej z obowiązujących przepisów prawa, jak też z warunków zewnętrznych pozwalających hetmanom na samowolne poszerzanie swoich kompetencji. Drugi: zróżnicowany stan zachowania spuścizn hetmańskich. Trzeci: brak dostatecznej wiedzy na temat zasad organizacji i funkcjonowania, jak też procesów archiwotwórczych (aktotwórczych i wstępnej archiwizacji) w kancelariach wojskowych w XVIII w., także tych działających przy hetmanach. Do tej pory na ten temat powstała pewna ilość prac o charakterze głównie przyczynkarskim² ${ }^{2}$ a interesującą i ciekawą od strony wyników próbę zmierzenia się z problemem istnienia tzw. archiwów hetmańskich podjął Krzysztof Syta, dokonująć klasyfikacji zachowanych w nich dokumentów i akt. Pokusił się też o określenie ich statusu prawnego³.

${ }^{2}$ Najczęstszym tematem są materiały do dziejów wojskowości w archiwach rodzinno-majątkowych, w tym i rodów „naznaczonych” urzędem hetmańskim - np. B. Ratusiński, Materiaty do dziejów wojskowości w Archiwum Dzikowskim Tarnowskich, „Studia i Materiały do Historii Wojskowości” 1962, t. VIII, s. 281-286; czy K. Tyszkowski, Archiwum hetmańskie w Podhorcach, „Przegląd Historyczno-Wojskowy” 1929, t. I, s. 269-271 oraz artykuły opublikowane w „Miscellanea Historico-Archivistica”, t. XIII, Warszawa 2001 (druk 2002). Wśród tych ostatnich studium mojego autorstwa, w którym podjąłem próbę przedstawienia funkcjonowania i procesów aktotwórczych w kancelariach regimentowych i chorągwianych w czasach saskich - T. Ciesielski, Źródła do dziejów regimentów i choragwi wojska koronnego z lat 1717-1763, „Miscellanea Historico-Archivistica", t. XIII, s. 81-92. Interesujące uwagi na temat kancelarii hetmańskiej i wojskowej zawiera studium C. Szadkowskiej, Ludwik Konstanty Pociej, hetman wielki Wielkiego Księstwa Litewskiego, $i$, ,Regestr” jego archiwum z roku 1720, „Archeion” 1973, t. LIX, s. 78-86.

${ }^{3}$ Nieopublikowana rozprawa doktorska „Archiwa hetmanów koronnych”, mps w Bibliotece Uniwersytetu Mikołaja Kopernika w Toruniu. Podstawowe tezy zostały przedstawione przez K. Sytę w artykułach: Dokumentacja wojskowa w archiwach hetmanów koronnych, „Miscellanea Historico-Archivistica", t. XIII, s. 51-67 oraz Archiwa hetmanów koronnych. Pojęcie, charakter i typologia dokumentacji, „Archiwa - Kancelarie - Zbiory” 2011, nr 2 (4), s. 63-105; a stan zachowania archiwów hetmańskich w artykule: Materiaty do przewodnika po archiwaliach hetmanów koronnych $w$ zasobach archiwalnych i zbiorach bibliotecznych, „Archiwa - Kancelarie Zbiory” 2012, nr 3 (5), s. 109-182. Wartościowe informacje na temat archiwów hetmańskich też w pracy K. Syty, Archiwa magnackie w XVIII wieku. Studium kultury kancelaryjno-archiwalnej, Toruń 2010. 


\section{KOMPETENCJE URZĘDU HETMAŃSKIEGO W XVIII W.}

W XVIII w. kilkakrotnie w sposób znaczący zmieniła się rola odgrywana przez hetmanów w państwie i armiach Rzeczypospolitej. Po raz pierwszy w pierwszej dekadzie tego stulecia, gdy na skutek zaniku autorytetu władzy monarszej, a wraz z nim kontroli ze strony instytucji cywilnych nad hetmanami, w trakcie Wielkiej Wojny Północnej doszło do największego rozrostu władzy buławy w całej historii istnienia urzędu. Nastąpiło to w sposób nieformalny, gdyż hetmani koronni i litewscy bez żadnych podstaw prawnych zawłaszczyli pełnię władzy nad wojskiem, ograniczoną jedynie tym, że nie mogli ustalać wielkości komputu, choć mogli zmieniać jego podział wewnętrzny i utrzymywać armię na niższej stopie liczebnej. Przejęli natomiast pełną kontrolę nad prowadzeniem działań zbrojnych i dyslokacją oddziałów, polityką kadrową w armiach (przede wszystkim obsadzania stanowisk dowódczych i oficerskich), jak też nad sprawami finansowania wojska, przede wszystkim w oparciu o wydawanie asygnat skarbowych (co należało do kompetencji podskarbich) oraz rozdziału hiberny i stacji. Do tego dochodziła duża samowola w wykorzystywaniu pozostających w ich dyspozycji pieniędzy przeznaczonych na utrzymanie wojska. Po wymuszonym traktatem w Altranstädt ustąpieniu przez Augusta II z tronu, hetman wielki koronny Adam Mikołaj Sieniawski stał się od 1706 roku czasowo najważniejszą osobą w Koronie, a w przypadku Michała Wiśniowieckiego na przeszkodzie, aby osiągnął taką samą pozycję w Wielkim Księstwie, stanęla opozycja ze strony innych przywódców republikantów, magnackich rodów litewskich oraz przejście na stronę Karola XII i Stanisława Leszczyńskiego w 1707 r. ${ }^{4}$

Olbrzymiej władzy powinna była towarzyszyć duża odpowiedzialność za losy państwa i troska o bezpieczeństwo szlachty. Tego ostatniego kolejni hetmani obu narodów w latach 1702-1716 nie byli w stanie zapewnić, choć niewątpliwie należy im przyznać, że utrzymali obie armie Rzeczypospolitej w stanie istnienia,

${ }^{4}$ W. Stanek, ,, Opisanie” urzędu hetmańskiego z 1717 roku i jego polityczne następstwa, „Studia i materiały do historii wojskowości" 1995, t. 37, s. 33; J.A. Gierowski, Między saskim absolutyzmem a złota wolnością. Z dziejów wewnętrznych Rzeczypospolitej w latach 1717-1715, Wrocław 1953, s. 107-109; idem, Polska wobec kampanii rosyjskiej Karola XII, [w:] idem, W cieniu Ligii Pólnocnej, Wrocław - Warszawa - Kraków - Gdańsk 1971, s. 22-92; Idem, „, Opisanie” urzędów centralnych przez konfederatów warszawskich, [w:] J.A. Gierowski (red.), O naprawę Rzeczypospolitej XVII-XVIII w. Prace ofiarowane Władysławowi Czaplińskiemu w 60 rocznicę urodzin, Warszawa 1965, s. 193-200; idem, The Polish-Lituanian Commonwealth in the XVIII century. From anarchy to well-organised state, Kraków 1996, s. 126; J. Wimmer, Wojsko Rzeczypospolitej w dobie wojny pótnocnej, Warszawa 1956, s. 84, 94-96 i n.; B. Popiołek, Królowa bez korony. Studium z życia i działalności Elżbiety z Lubomirskich Sieniawskiej ok. 1669-1729, Kraków 1996, s. 56-75, J. Ronikier, Hetman Adam Sieniawski i jego regimentarze. Studium z historii mentalności szlachty polskiej 1706-1725, Kraków 1992, s. 66-78. 
a nawet podjęli pewne działania modernizujące. Te osiągnięcia zaginęły jednak w ogromie nieporadności obu armii Rzeczypospolitej w zmaganiach wojennych, a szlachta przede wszystkim dostrzegała liczne przypadki zawłaszczania atrybutów władzy królewskiej, innych urzędników i instytucji państwowych, łamania prawa i oprymowania szlachty przez osoby dzierżące buławy, jak też ich skorumpowanie i dążenie do osiągania korzyści materialnych kosztem państwa i „współbraci”. W 1716 r. reprezentujący interesy szlachty i wojska „obojga narodów” konfederaci tarnogrodzcy zaliczyli hetmanów w poczet swoich wrogów - Sieniawskiego osadzili w areszcie we Lwowie, Pociej tylko dzięki zachowaniu dużej ostrożności i szczęśliwemu zbiegowi okoliczności uniknął jego losu - a następnie w trakcie rokowań z królem konfederaci od lata 1716 r. domagali się ograniczenia uprawnień władzy buławy ${ }^{5}$. Efektem tego były ograniczające władzę hetmanów zapisy $\mathrm{w}$ artykule $\mathrm{V}$ traktatu warszawskiego i w konstytucjach sejmu niemego, które zakazywały im:

- wydawania asygnat skarbowych i hibernowych;

- zwoływania komisji hibernowych;

- przetrzymywania pieniędzy przeznaczonych na opłacanie żołnierzy;

- kierowania wojska na kwatery;

- utrzymywania wojskowego aparatu fiskalnego;

- wykorzystywania wojska i posiadanej władzy dla swoich prywatnych celów;

- preferowania cudzoziemców w obsadzie stanowisk oficerskich;

- utrzymywania jakichkolwiek kontaktów dyplomatycznych z ,postronnemi Pany".

Hetmani zobowiązani zostali przy obejmowaniu urzędu do złożenia przysięgi, której rota obligowała osoby dzierżące buławy do trzymania wojska z dala od spraw wewnętrznych kraju, aby nie ingerowało w tok pracy sejmików, wybory posłów, deputatów oraz urzędników ziemskich i sądowych. W okresie bezkrólewia wojsko i sami hetmani powinni byli przebywać na granicach państwa, nie przeszkadzając w elekcji i nie opowiadając się po stronie żadnego z kandyda-

${ }^{5}$ Pamiętniki Krzysztofa Zawiszy, wojewody mińskiego (1666-1721), wyd. J. Bartoszewicz, Warszawa 1862, s. 310, 329-333; [E. Otwinowski], Dzieje Polski pod panowaniem Augusta II od roku 1696-1728, wyd. J. Czech, Kraków 1849 s. 275-276, 283-286; A. Prochaska, Konfederacja tarnogrodzka, „Przewodnik Naukowy i Literacki”, 45, 1917, z. 5, s. 439-442, z. 6, s. 528-529, z. 7, s. 643-657, z. 8, s. 756-768; W. Stanek, „Opisanie” urzędu hetmańskiego..., s. 33-34; J.A. Gierowski, Między saskim absolutyzmem..., s. 295-297; idem, „Opisanie” urzędów centralnych..., s. 201-211; J. Wimmer, op.cit., s. 411-414; A. Sowa, Pociej Ludwik Konstanty, [w:] Polski Stownik Biograficzny, t. XXVII, Wrocław 1983, s. 44; A.K. Link-Lenczowski, Sieniawski Adam Mikołaj, [w:] Polski Słownik Biograficzny, t. XXXVII, Warszawa - Kraków 1996-1997, s. 112-113; T. Ciesielski, Hetmani Rzeczypospolitej Obojga Narodów w XVIII wieku (lata 1717-1794), „Tarnowskie Studia Historyczne” 2011, t. II, s. 89-90. 
tów do tronu. Armia nie mogła być wykorzystywana przy egzekucji wyroków sądowych, ani stanowić miejsca azylu dla osób skazanych w procesach karnych i cywilnych. Podstawowymi obowiązkami hetmanów było utrzymywanie wojska w „dobrym porządku” i dyscyplinie, a na wypadek konfliktu zewnętrznego lub wewnętrznego - skuteczna obrona Rzeczpospolitej6.

Przede wszystkim przywrócono moc obowiązywania dawniej ustanowionych praw, które ograniczały kompetencje urzędu hetmańskiego, zwłaszcza w kwestiach związanych z finansowaniem armii, tzw. władzy pióra, a co za tym idzie z możliwością oddziaływania w sposób nieformalny na życie wewnętrzne państwa. Pozostawiono im tzw. władzę miecza, czyli dowództwo nad wojskiem, które zostało ograniczone w czasie pokoju, gdyż nie mogli swobodnie przemieszczać i koncentrować oddziałów ani dokonywać zmian w kompucie. Podlegali w tym kontroli ze strony cywilnego organu władzy, jakim były trybunały skarbowe koronny i litewski, którym konstytucje sejmu niemego nadały stosunkowo szerokie uprawnienia. Jednak w praktyce taka kontrola sprowadzała się jedynie do stwierdzenia, czy istniały i popisały się przed komisarzami wojewódzkimi wszystkie oddziały, a także czy ich struktury organizacyjne były zgodne z komputem, jeżeli chodzi o liczbę stawek żołdowych.

Należy stwierdzić, że zapisy w traktacie warszawskim i konstytucjach sejmowych opisujące władzę buław były nieprecyzyjne i w sumie mało rygorystyczne. Zwłaszcza, że w 1716/1717 r. nie ograniczono władzy hetmanów w stosunku do prerogatyw nadanych im konstytucjami sejmowymi zXVIw. i początków XVII w. ${ }^{7}$, a jedynie pozbawiono ich uprawnień nabytych niezgodnie z prawem przez kolejne ,pokolenia” hetmanów w XVII w. i pierwszych dekadach XVIII w. Powodowało to, że od strony formalnoprawnej w latach 1717-1764/1766 sprawujący dożywotnią władzę nad wojskiem hetmani wciąż cieszyli się tak rozległymi prerogatywami, jak:

- dowództwo operacyjne nad armią;

- zwierzchnictwo nad fortecami i garnizonami;

- zwierzchnia władza nad artylerią;

${ }^{6}$ Volumina Legum. Prawa, konstytucje i przywileje Królestwa Polskiego, Wielkiego Księstwa Litewskiego $i$ wszystkich prowincji należacych na walnych sejmach uchwalonych, wyd. J. Ohryzko (dalej VL), t. 6, Sankt Petersburg 1860, s. 125-128, 131-132; J. Wimmer, op.cit., s. 440-441; T. Ciesielski, Zabiegi hetmanów o rewizję uchwat sejmu niemego i odzyskanie komendy nad autoramentem cudzoziemskim a sejmy w latach 1717-1724 (prolegomena), [w:] J. Muszyńska (red.), Rzeczpospolita w dobie Wielkiej Wojny Pótnocnej, Kielce 2001, s. 61-62; idem, Armia koronna..., s. $133-134$.

7 VL, t. 2, Sankt Petersburg 1859, s. 308, 330, 345; S. Woliński, Urzędy hetmańskie w świetle ustawodawstwa polskiego, „Przegląd Historyczno-Wojskowy” 1933, t. 6, z. 1, s. 61-80; S. Kempski, Władza buławy, „Przegląd Historyczno-Wojskowy” 1934, t. 7, z. 2, s. 182-215. 
- pełny nadzór nad wszystkimi oddziałami wchodzącymi w skład armii; kontrola ich stanów osobowych, wyposażenia oraz zdolności bojowych;

- praktycznie nieograniczona władza dyscyplinarna i sądownicza; zwierzchność nad kilkustopniowym i oddzielnym dla obu autoramentów sądownictwem wojskowym, którego najwyższą instancją były sądy hetmańskie;

- prawo wydawania regulaminów ogólnowojskowych i specjalistycznych, a także regulaminów organizacyjnych dla regimentów autoramentu cudzoziemskiego oraz regulujących życie w twierdzach i garnizonach;

- wpływania na organizację wewnętrzną oddziałów autoramentu cudzoziemskiego;

- prawo zwoływania kół wojskowych i wyznaczania przedstawicieli armii na zjazdy publiczne;

- prawo mianowania regimentarzy oraz urzędników wojskowych;

- prawo wysuwania i opiniowania kandydatów na dowódców chorągwi oraz regimentów;

- wyłączność na wydawanie rozkazów zatwierdzających awanse królewskie (tzw. forsztelacji) w obrębie starszej kadry oficerskiej autoramentu cudzoziemskiego, tj. od stopnia podpułkownika;

- prawo zatwierdzania awansów oficerów do stopnia porucznika w jeździe narodowego zaciągu i majora w autoramencie cudzoziemskim;

- władza rozdawnicza nad stosunkowo niewielkimi funduszami largicyjnymi - po 100000 zł rocznie, z których część pochłaniały pensje urzędników wojskowych.

- dowództwo nad oddziałami noszącymi miano hetmańskich (każdy hetman był szefem regimentu pieszego i dragońskiego oraz rotmistrzem chorągwi pieszej, husarskiej i pancernej / petyhorskiej) i prawo stałej asysty wojskowej przy swoim boku ${ }^{8}$.

Zakres władzy hetmańskiej nie był przy tym stały, a po przełamaniu w połowie lat 20. XVIII w. najgłębszego kryzysu władzy buławy w dotychczasowych jej dziejach, zaczął rosnąć. W dużej mierze w sposób nieformalny, a wpływ na to miała pozycja kolejnych hetmanów i regimentarzy generalnych w państwie. Sprzyjała temu duża bierność i brak większego zainteresowana armiami Rzeczypospolitej ze strony Augusta II (w ostatnich latach panowania) oraz Augusta III i ich saskich ministrów. Pozwoliło to władzy hetmańskiej rozstrzygnąć na swoją korzyść spór w kwestii nominacji oficerskich, doprowadzić do niemal całkowite-

8 T. Ciesielski, Armia koronna..., s. 134-147; idem, Armia Wielkiego Księstwa Litewskiego w latach 1717-1775. Komput, budżet i struktury organizacyjne oddziatów, [w:] S. Górzyński, M. Nagielski (red.), Studia z dziejów Wielkiego Księstwa Litewskiego: (XVI-XVIII wieku), Warszawa 2014, s. 67. 
go zniesienia ograniczeń w zakresie swobody przemieszczania i koncentrowania większych grup wojska, jak i prowadzenia działalności dyplomatycznej ${ }^{9}$. Co więcej, wręcz usankcjonowane zostało prawo hetmanów do prowadzenia polityki zagranicznej, zmieniania dyslokacji oddziałów i kierowania ich do asysty zjazdów publicznych czy na koła wojskowe, a nawet podejmowania zakrojonych na szeroką skalę akcji policyjno-wojskowych (zwalczanie ruchów hajdamackich, zajęcie ordynacji ostrogskiej w $1754 \mathrm{r}^{10}$ ).

Ponowne wzniesienie się władzy hetmańskiej ponad prawne i zwyczajowe kompetencje sprawiło, że stała się ona łatwym, a przy tym popieranym przez szlachecką opinię publiczną, celem ataku obozu reformatorskiego spod znaku Familii w latach 1763-1766. Doprowadziło to do ograniczenia władzy osób dzierżących buławy poprzez ustanowienie komisji wojskowych, oddzielnej dla Korony w 1764 r., a dla Litwy w 1766 r. Ich zadaniem było wspomaganie hetmanów w sprawach sądowniczych i administrowania wojskiem, a zwłaszcza w procesie rozliczania stanów oddziałów, ale w rzeczywistości stały się instytucjami nadzorującymi hetmanów, które wkrótce przejęły pełnię władzy nad obiemia armiami ${ }^{11}$. Przyczynili się do tego sami hetmani, którzy bojkotując w latach 60 . XVIII w. powstanie komisji, utracili możliwości przejęcia kontroli nad ich pracami, choć zgodnie z konstytucjami sejmowymi mieli tym komisjom przewodniczyć. W konsekwencji władza hetmańska została sprowadzona do roli niemal jedynie reprezentacyjnej, gdyż z dawnych uprawnień pozostała im mocno okrojona władza sądownicza.

Hetmani podejmowali próby odzyskania dawnej władzy, co sprawiło, że w 1768 r. przywrócono im pewne, choć tylko honorowe prerogatywy, a w latach 1774-1775 odzyskali władzę nad armiami w związku z marginalizacją roli skompromitowanych komisji wojskowych. W 1775 r. na sejmie ustanowiono Departament Wojskowy Rady Nieustającej, którego prezesami mieli być hetmani, a nowa rota przysięgi zobowiązywała wojsko do bezwzględnego posłuszeństwa władzy buławy $^{12}$. Jednak i tym razem tryumf buławy był krótkotrwały, gdyż w $1776 \mathrm{r}$. przywrócono rotę przysięgi z 1764 r., i powiększono kompetencje Departamentu Wojskowego $^{13}$. Hetmani koronni Franciszek Ksawery Branicki i Seweryn Rze-

${ }^{9}$ W. Zarzycki, Dyplomacja hetmanów w dawnej Polsce, Warszawa - Poznań 1976, s. 52 i n.; T. Ciesielski, Armia koronna..., s. 137-140.

10 T. Ciesielski, Armia koronna..., s. 497-532; T. Ciesielski, O hajdamaczyźnie w latach 1733-1763, [w:] P. Borek (red.), W kręgu Hadziacza A.D. 1658. Od historii do literatury, Kraków 2008, s. 181-198; idem, Гайдамацтво 1717-1763 рр. Організація руху та загонів, тактика дій $i$ бою, „Збірник Харківського історико-філологічного товариства”, Нова серія, t. 14, Харків 2011, s. 15-33.

${ }^{11}$ VL, t. 7, Sankt Petersburg 1860, s. 29-30.

12 VL, t. 8, Sankt Petersburg 1860, s. 74-76, 101.

13 T. Korzon, Wewnętrzne dzieje Polski za Stanisława Augusta 1764-1794, t. 3, Kraków - Warszawa 1897, s. 175; W. Stanek, „, Opisanie” urzędu hetmańskiego..., s. 41; L. Ratajczyk, Kierowni- 
wuski nie pogodzili się z tymi zmianami, co sprawiło, że utracili wpływ na Departament Wojskowy, którym przewodniczył w pełni uzależniony od ambasadora rosyjskiego i króla hetman polny litewski Józef Sosnowski ${ }^{14}$.

Do kolejnego ograniczenia władzy buławy doszło po ustanowieniu na Sejmie Czteroletnim podległej Straży Praw nowej Komisji Wojskowej, wspólnej dla Korony i Litwy, od pracy w której odsunięto hetmanów. U schyłku dni Rzeczypospolitej Konfederacja Targowicka przywróciła w 1792 r. pełnię władzy nad wojskiem, taką jaką posiadali przez 1764 r. Jednak była ona iluzoryczna w obliczu redukcji armii i ingerowania w sprawy wojskowe tak władz konfederackich, jak i ambasadora rosyjskiego. $Z$ zachowanych archiwaliów wynika przy tym, że z nadarzającej się okazji przywrócenia dawnego blaskowi urzędowi hetmańskiemu próbował skorzystać Seweryn Rzewuski ${ }^{15}$, ale z ograniczonym skutkiem.

Największe kompetencje hetmani posiadali na przełomie pierwszej i drugiej dekady oraz od drugiej połowy lat 30 . do połowy lat 60 . XVIII w. Następnie przez blisko trzy dekady nie posiadali żadnej władzy nad wojskiem. Od 1768 r. hetmani byli ministrami Rzeczypospolitej, „przeważnie nieczynnymi urzędnikami podporządkowanymi Radzie Nieustającej oraz królowi”16, bardzo hojnie jednak przy tym opłacanymi, gdyż zachowali wysokie pensje przyznane im na sejmie 1717 r. - pobierali rocznie hetmani wielcy 120 tys. zł, a polni 80 tys. zł. Do tego dochodziły całkiem pokaźne kwoty pieniężne z tytułu szefowania oddziałami noszącymi miano hetmańskich (po regimencie pieszym i dragońskim oraz chorągwi pieszej, husarskiej i pancernej / petyhorskiej dla każdego z czterech hetmanów) łącznie każdy z hetmanów koronnych otrzymywał z tego tytułu dodatkowo ponad 50 tys. $z \nmid$ rocznie, a litewski ok. 40 tys. $z^{17}$.

\section{KANCELARIE HETMAŃSKIE}

Znaczenie urzędu hetmana, jego kompetencje i zakres realnej władzy nad wojskiem niewątpliwie znajdowały swoje odzwierciedlenie organizacji, funkcjonowaniu i procesach archiwotwórczych zachodzących w kancelariach woj-

ctwo wojskowe i doktryna wojenna Rzeczypospolitej przed Sejmem Czteroletnim, „Zeszyty Naukowe WAP" 1973, nr 76, s. 149; idem, Przezwyciężenie kryzysu militarnego Polski przed reformami Sejmu Czteroletniego, Warszawa 1975, s. 21-23.

${ }^{14}$ Z. Zielińska, Sosnowski Józef Sylwester, Polski Stownik Biograficzny, t. XL, Warszawa - Kraków 2001, s. 563.

15 Dowodzą tego zachowana korespondencja oraz raporty nadsyłane z oddziałów i garnizonów armii koronnej, Archiwum Narodowe w Krakowie (ANKr), Archiwum Podhoreckie (APodh), pudła I, II, V, VII, VIII, XII, XIII.

${ }^{16}$ L. Ratajczyk, Przezwyciężenie kryzysu militarnego..., s. 23.

17 T. Ciesielski, Hetmani Rzeczypospolitej..., s. 93. 
skowych działających przy hetmanach. Wydaje się, że zmiany w kompetencjach hetmańskich na przestrzeni XVIII w. wpływały korzystnie przynajmniej na proces archiwotwórczy. Wzmocnienie władzy buławy, jak i narzucone jej w 1717 r. ograniczenia, przyczyniły się do większej skrupulatności w prowadzeniu przez hetmanów dokumentacji wojskowej związanej ze sprawowanym urzędem, ale należy podkreślić, że dbano o nią od XVI w. Prawdopodobnie od samego początku istnienia urzędu hetmańskiego funkcjonowały przy nim kancelarie wojskowe ${ }^{18}$. Nie były to przy tym kancelarie prywatne, gdyż środki na ich utrzymanie pochodziły ze skarbu państwowego. W XVIII w. zostało to usankcjonowane poprzez umieszczanie wydatków na kancelarie w budżetach largicyjnych. W Koronie wydzielono na kancelarie buławy wielkiej 2000 zł, a buławy polnej 500 zł rocznie - takie też kwoty zostały umieszczone w rozliczeniu largicji z lat 1727, 1731, $1759^{19}$. Znacznie większe środki przeznaczono na utrzymanie kancelarii w armii Wielkiego Księstwa Litewskiego: $6000 \mathrm{zł}^{20}$. Wydaje się jednak, że wydatki na cele kancelaryjne były znacznie większe, gdyż obok wojskowych istniały też kancelarie obsługujące urząd hetmański. Niewątpliwie od 1764 r. w Koronie, a od 1766 r. na Litwie doszło do oddzielenia się kancelarii wojskowych prowadzących dokumentację obu armii, gdyż przeszły one pod zarząd najpierw komisji wojskowych, a następnie Departamentu Wojskowego Rady Nieustającej. Ograniczy się też przepływ dokumentacji wojskowej przez kancelarie hetmańskie, dotychczas bardzo duży.

Analiza zachowanych spuścizn po hetmanach koronnych i litewskich wykazuje, że w pierwszych siedmiu dekadach XVIII w. znacząco zwiększyła się ilość powstających dokumentów i akt wojskowych, zwłaszcza w przypadku armii Wielkiego Księstwa Litewskiego (nie może to dziwić, gdyż dopiero od 1717 r. stała się ona od strony formalnoprawnej stałą). Okres pokoju zwiększył rolę korespondencji prowadzonej przez hetmanów z podwładnymi, zarówno tej o charakterze czysto służbowym (raporty i meldunki, prośby o awanse, nagrody, zwolnienie ze służby, urlopy itp.), jak i na wpół prywatnej lub związanej z niewojskową działalnością publiczną (informacje o sejmikach i innych ważnych wydarzeniach politycznych, przesyłanie korespondencji hetmanów do osób niezwiązanych z armią, realizowanie zakupów dla hetmana itp.). Tymczasem wszyscy osiemnastowieczni hetmani aktywnie uczestniczyli w życiu politycznym, a przede wszystkim byli właścicielami rozległych majątków ziemskich, typowych latyfundiów magnackich, z czym wiązało się wytwarzanie znacznej ilości dokumentacji innego typu. Sprawiało to, że w pragmatyce obsługi kancelaryjnej wielopłaszczyznowej działalności Adama

\footnotetext{
${ }_{18}$ K. Syta, Dokumentacja wojskowa..., s. 51-52 nn.

19 T. Ciesielski, Armia koronna..., s. 48.

20 T. Ciesielski, Armia Wielkiego..., s. 67.
} 
Mikołaja Sieniawskiego, Józefa Potockiego, Jana Klemensa Branickiego, Michała Kazimierza Radziwiłła czy Stanisława Mateusza i Wacława Rzewuskich wykształciły się odrębne kancelarie hetmańskie, działające niezależnie od kancelarii prywatnych i ekonomiczny $\mathrm{ch}^{21}$, zapewne obsługiwane przez specjalnie zatrudnianych, wysoko wykwalifikowanych pracowników. Działająca przy boku Sieniawskiego kancelaria nazywana była „,hetmańską”, „buławy wielkiej” czy po prostu „hetmana Sieniawskiego”. Rzewuscy posiadali „kancelarię wojskową”"22, a na dworze Branickiego określana była, jeżeli zawierzyć wspomnieniom Michała Starzeńskiego, jako „biuro wojenne”, którego drugim pisarzem był pod koniec lat 50. XVIII w. niejaki Sobolewski ${ }^{23}$. Obok niego w kancelarii na dworze białostockim wydzielona była - według innego pamiętnikarza, Marcina Matuszewicza: „cudzoziemska ekspedycja” (taka sama istniała na dworze wołczyńskim Czartoryskich), „hetmańska cudzoziemska ekspedycja” lub „cudzoziemska ekspedycja hetmańska", która odpowiadała za korespondencję otrzymywaną i wysyłaną za granicę, zapewne także wojskową. Kolejnymi jej sekretarzami byli: do 1759 r. Jan Beck, a po nim ksiądz Antoni Betański ${ }^{24}$. Co więcej, istniała odpowiednia procedura załatwiania spraw przez Branickiego, który codzienne rano „od szóstej do siódmej załatwiał sprawy gospodarcze, od siódmej do ósmej przychodzili sekretarze cywilni czytać mu listy i odbierać rozkazy do odpowiedzi na nie", a dopiero po godzinie jedenastej, po mszy świętej ,podpisywał wszystkie akta i papiery wojskowe" 25 . Na dworze białostockim działały przy tym przynajmniej trzy, a zapewne i więcej kancelarii: cywilna, osobista oraz wojskowa, mająca rozległy zakres zadań, gdyż zajmowała się oddzielnie sprawami całej armii, jak też oddziałów służących w Białymstoku, i obsługą urzędu hetmańskiego ${ }^{26}$.

Zapewne personel nie tylko kancelarii Branickiego, ale innych kancelarii hetmańskich, był wieloosobowy - obok pisarzy i kancelistów zatrudnieni byli też kopiści, o czym mogą świadczyć kopiariusze zawierające uniwersały i roz-

${ }^{21}$ O prowadzeniu na dworach osób sprawujących urzędy hetmańskie kilku kancelarii: T. Zielińska, Archiwa wielkich rodów Rzeczypospolitej dziedzictwem narodów Europy Środkowo-Wschodniej, „Archiwista Polski”, 2 (1999), s. 33-40; K. Syta, Archiwa magnackie od XVI do XVIII w. - możliwości i kierunki badawcze, [w:] J. Urwanowicz (red.), Władza i prestiż. Magnateria Rzeczypospolitej w XVI-XVIII wieku, Białystok 2003, s. 679-691; K. Łopatecki, W. Walczak, Wstęp, [w:] K. Łopatecki, W. Walczak (oprac.), Pałac Branickich w Białymstoku, t. I: Inwentarze z XVII i XVIII stulecia, cz. 1, Białystok 2012, s. 113-115.

${ }^{22}$ K. Syta, Archiwa magnackie w XVIII wieku..., s. 53.

${ }^{23}$ M. Starzeński, Na schytku dni Rzeczypospolitej. Kartki z pamiętnika Michała Starzeńskiego (1757-1795), wyd. H. Mościcki, Warszawa 1914, s. 4; K. Syta, Archiwa magnackie..., s. 53.

${ }^{24}$ M. Matuszewicz, Diariusz życia mego, oprac. B. Królikowski, komentarz Z. Zielińska, Warszawa 1986 , t. 1 , s. $639-643,657,660,683,694-696,833,834,854$, t. 2. , s. $11,13,14,19,55$, 74-75, 429, 492-493, 536; K. Syta, Archiwa magnackie..., s. 54.

${ }^{25}$ M. Starzeński, op.cit., s. 6.

${ }^{26}$ K. Łopatecki, W. Walczak, Wstęp..., s. 113-114. 
kazy królewskie, hetmańskie i regimentarzy, rozliczenia oddziałów, czy odpisy i regestry korespondencji wpływającej, jak i wychodzącej z kancelarii hetmańskich. Wiele takich ksiąg zachowało się w spuściźnie po J. Potockim ${ }^{27}$, M.K. Radziwille $^{28}$ czy J.K. Branickim ${ }^{29}$. W przypadku tego ostatniego w jego spuściźnie archiwalnej znajdują się też kopiariusze korespondencji prowadzonej przez Potockiego z wysokimi urzędnikami i dowódcami wojsk państw ościennych, regimentarzami wojsk koronnych, ministrami i dostojnikami Rzeczypospolitej z lat $1735-1738^{30}$. Co ciekawe, w spuściźnie po Sieniawskim znajduje się z kolei kopiariusz z korespondencji wychodzącej z kancelarii jego nominalnego podwładnego, hetmana polnego Stanisława Mateusza Rzewuskiego z lat $1721-1723^{31}$.

Kancelarie czy też biura wojskowe utrzymywane były przez hetmanów, ale przez wzgląd na wysokość pobieranego przez nich wynagrodzenia, a także możliwości wykorzystania dla opłacania kancelistów funduszu largicyjnego, niewątpliwie - przynajmniej pośrednio - finansowane były ze skarbu państwowego. Co więcej: sami hetmani nadawali swoim kancelariom rangę publicznych, o czym może świadczyć użyte w przedrukowanym przez Samuela Brodowskiego liście Józefa Potockiego do Aleksandra Krassaua stwierdzenie, że wszystkie patenty oficerskie od stopnia chorążego do majora winny wychodzić z kancelarii „hetmańskiej”32.

Niestety nie zachowały się instrukcje czy regulaminy regulujące działalność kancelarii hetmańskich i dlatego nie sposób jednoznacznie stwierdzić, czy przekonaniu o tak dużym publicznym, nie tylko wojskowym, znaczeniu kancelarii hetmańskich, towarzyszyła jakaś specjalna troska o zabezpieczenie wytwarzanych przez nią dokumentacji. Wydaje się, że tak, a świadczą o tym choćby wspomniane powyżej kopiariusze rozkazów i korespondencji hetmańskich. Domniemywać też można, że za życia hetmanów dokumentacja wojskowa prowadzona i przechowywana była oddzielnie od pozostałych dokumentów i akt o charakterze publicznym, a tym bardziej prawno-majątkowych i rachunkowo-gospodarczych. Po śmierci hetmana zazwyczaj jednak ich spadkobiercy przestawali otaczać dokumentację wojskową specjalną troską (zdaje się, że nie dotyczy to praktyki na

27 Archiwum Główne Akt Dawnych w Warszawie (AGAD), Archiwum Publiczne Potockich (APPot), nr 59, 60, 127-129; Российская национальная библиотека Санкт-Петербург (РНБ), Отдел рукописей, ф. 957: Собрание польских рукописей, nr Pol. IV 282.

${ }^{28}$ AGAD, Archiwum Radziwiłłowskie (AR), dz. VII, nr 1a, 1b, 1c, 1d, 2, 3a, 3b, 3c.

${ }^{29}$ AGAD, Archiwum Roskie (ARos), Korespondencja (K), Suplement (Supl.), nr 4-22.

${ }^{30}$ AGAD, ARos, Militaria (M), pudło 3; AGAD, ARos, K, Supl., nr 27.

${ }^{31}$ Biblioteka im. Książąt Czartoryskich w Krakowie (BCz), nr 2448.

${ }^{32}$ S. Brodowski, Corpus Juris Militaris Polonicum, w którym się znajdują artykuły woienne hetmańskie autoritate seymu walnego koronnego r. 1609 za króla jmci Zygmunta III w Warszawie aprobowane..., Elbląg 1753 (CIM), s. 112. 
dworze nieświeskim Radziwiłłów i podhoreckim Rzewuskich), a traktując ją jako prywatną część masy spadkowej, dołączali do reszty pozostałej po zmarłym spuścizny aktowej, poddając ją wstępnym procesom archiwizacji. Tak było w przypadku papierów wojskowych Sieniawskiego czy Branickiego. Jeżeli chodzi o te pierwsze, to do ich uporządkowania przystąpiono w drugiej dekadzie XVIII w., jeszcze za życia hetmana, a dokończono prace już na zlecenie drugiego męża córki hetmana, Augusta Czartoryskiego w latach 30. XVIII w. ${ }^{33} \mathrm{~W}$ ich trakcie zadbano o wydzielenie dokumentacji związanej z organizacją i dowodzeniem armią koronną przez Sieniawskiego ${ }^{34}$, ale już korespondencję z podkomendnymi połączoną z „cywilną" ${ }^{35}$. Co więcej - w przypadku pozostałej dokumentacji wojskowej można dostrzec przypadki przemieszania regulaminów, raportów i inny akt wojskowych wytworzonych w kancelarii Sieniawskiego z zebranymi przez Czartoryskich w trakcie ich działalności politycznej i wojskowej w XVIII w. Stąd przykładowo - wśród raportów o stanach oddziałów wojskowych w pierwszych trzech dekadach XVIII w. znajdują się raporty sporządzone przez regimenty litewskie, a do akt o charakterze normatywnym dołączony został scenariusz i regulaminy opracowane dla potrzeb kampamentu czerniakowskiego w $1732 \mathrm{r}^{36}$ Spory kompleks akt w tzw. Sieniawie stanowi też dokumentacja wytworzona w związku z szefowaniem przez Augusta Czartoryskiego regimentowi pieszemu gwardii koronnej w latach 1729-1782 (ale akta zachowały się z lat 20.-60. XVIII w.) ${ }^{37}$. Papiery wojskowe Branickiego zostały dołączone do reszty jego spuścizny archiwalnej dopiero w trakcie kolejnego, zarządzonego przez wdowę, Izabelę z Poniatowskich Branicką, etapu prac nad uporządkowaniem archiwum białostockiego prowadzonych przez Stanisława Karwowskiego ${ }^{38}$ - zapewne pomiędzy 1780 r. a 1793 r., gdy dokumentacja wojskowa przemieszana była już z gospodarczą i zbiorem gazet w „trzeciej” skrzyni oraz z papierami publicznymi w skrzyni „piątej”39. W kolejnych latach cała spuścizna po Branickim, a zwłaszcza archiwum hetmańskie, uległa podziałowi i obecnie części składowe archiwum można znaleźć w kil-

33 O pracach porządkowych i inwentaryzacyjnych w XVIII w., K. Syta, Archiwa magnackie..., s. $98-99,100,131-132$.

34 Jednostki zawierające dokumenty i akta wojskowe nie są zebrane w jedną całość, a posiadają sygnatury pomiędzy $\mathrm{BCz}, \mathrm{nr} 1684$ a 3126 . W miarę dokładnie wyselekcjonował te jednostki K. Syta, Materiały do przewodnika..., s. 166-173.

$35 \mathrm{BCz}, \mathrm{nr} 2734,2747,2517,2574,2760,2766,2882$, oraz jednostki korespondencyjne od nr 5756 do nr 5999 (niemal w każdej znajduje się jakiś list od podkomendnego lub przedstawiający działania wojenne); K. Syta, Materiały do przewodnika..., s. 166-175.

${ }^{36} \mathrm{BCz}, \mathrm{nr} 2632,2650$.

${ }^{37} \mathrm{BCz}, \mathrm{nr}$ 2630, 2648, 2649; T. Ciesielski, Źródła do dziejów regimentów..., s. 88-89.

${ }^{38} \mathrm{O}$ pracach porządkowych w archiwum białostockim Branickiego: K. Łopatecki, W. Walczak, Wstep..., s. 114-118.

${ }^{39}$ K. Syta, Archiwa magnackie..., s. 262. 
ku zespołach przechowywanych w Archiwum Głównym Akt Dawnych w Warszawie: Archiwum Roskim (przede wszystkim działy: Militaria, Korespondencja i Korespondencja Suplement), Archiwum Branickich z Suchej oraz Zbiór Anny Branickiej (przede wszystkim dział I, zatytułowany Kancelaria hetmańska) ${ }^{40}$. Pod tym względem znacznie korzystniej prezentuje się archiwum podhoreckie Rzewuskich, w którym dokumentacja wojskowa kolejnych trzech przedstawicieli rodu dzierżących buławy koronne, Stanisława Mateusza (1706-1728), Wacława (1752-1774) i Seweryna (1774-1795), została ściśle wydzielona już przy pierwszych pracach porządkowych, czego dowodzi sumariusz z początku XIX w. ${ }^{41} \mathrm{Co}$ więcej, choć w trakcie burzliwych losów archiwum podhoreckiego została przemieszana z innymi materiałami, to nie na tyle, aby zatracić swoją odrębnośćc ${ }^{42}$ i po pracach porządkowych wykonanych już w Archiwum Narodowym w Krakowie (za zakończonych dopiero pod koniec pierwszej dekady XXI w.) zachowała czytelne wyodrębnienie, choć rozdzielona jest między cztery działy: Podhorce I, Podhorce II. Podhorce III (zwane Tekami Andrzeja Potockiego) oraz Podhorce $\mathrm{IV}^{43}$. W przypadku dokumentacji wojskowej Michała Kazimierza Radziwiłła została ona połączona z aktami powstałymi w związku z istnieniem licznych milicji radziwiłłowskich w XVII i XVIII w., jak też ze szczątkami papierów po innych aktywnych na polu wojskowym przedstawicielach rodu. Jednak za sprawą zagrabienia przez Rosjan jeszcze w XVIII w. kancelarii wojskowych (hetmańskich) Krzysztofa i Janusza Radziwiłłów ${ }^{44}$, zasadniczy trzon działu VII Archiwum Radziwiłłowskiego stanowią papiery wojskowe dokumentujące istnienie milicji prywatnej i działalności hetmańskiej Michała Kazimierza Radziwiłła. Podobną dominację można dostrzec w przypadku korespondencji wojskowej w dziale V. Na tle dziejów i stanu zachowania archiwów Sieniawskiego, Branickiego, Rzewuskiego i Radziwiłła osobliwe są losy kancelarii hetmańskiej Józefa Potockiego, która nie zachowała się w całości, a rozdzielona została pomiędzy kilka archiwów rodowych ${ }^{45}$. Z domem Potockich związane jest tylko jedno z nich - Archiwum

${ }^{40}$ K. Syta, Materiaty do przewodnika..., s. 116-143 - wykaz bardzo obszerny, ale niepełny, pominięto ważną dokumentację znajdującą się w AGAD.

${ }^{41}$ K. Syta, Archiwa magnackie..., s. 181.

${ }^{42} \mathrm{Z}$ wydzieleniem akt wojskowych nie miał problemów w latach 20 . XX w., czyli po przeniesieniu archiwum Rzewuskich do podtarnowskich Gumnisk, Kazimierz Tyszkowski: Archiwum hetmańskie..., s. 269-271.

${ }^{43}$ K. Syta, Materiaty do przewodnika..., s. 149-166 - wykaz bardzo obszerny, wymagający uzupełnienia o dział IV Archiwum Podhoreckiego.

${ }_{44}$ РНБ, ф. 971, оп. 2, Автографи Дубравскаго, 96, 115, 119, 234; ф. 957, Pol. IV 133.

${ }^{45}$ K. Syta, Materiały do przewodnika..., s. 148-149 - wykaz nieadekwatny do rzeczywistego stanu zachowania spuścizny po J. Potockim. 
Publiczne Potockich ${ }^{46}$. Część ksiąg - kopiariuszy korespondencji, jak też luźne odpisy listów, znajdują się w spuściźnie po Janie Klemensie Branickim ${ }^{47}$. Jeżeli nie są to odpisy sporządzone na zlecenie Branickiego, to może zostały przejęte przez niego jako następcy na urzędzie hetmana wielkiego na zasadzie dziedziczenia ważnej dokumentacji wojskowej mającej charakter publiczny. Możliwość istnienia takiej praktyki dopuszcza K. Syta, ale w odniesieniu do akt określonych przez niego jako będące proweniencji publicznej, a skłania go do tego fakt, że w spuściźnie po Sieniawskim znajdują się akta komisji wojskowych z czasów hetmaństwa Stanisława Jabłonowskiego ${ }^{48}$.

Nie zachowały się archiwa wojskowe po dwóch ostatnich wielkich koronnych Franciszku Ksawerym Branickim ${ }^{49}$ i Piotrze Ożarowskim oraz jednym polnym - Stanisławie Chomentowskim, jak też po niemal wszystkich hetmanach litewskich: Ludwiku Konstantym Pocieju, Michale Serwacym Wiśniowieckim, Michale Józefie Massalskim, Michale Kazimierzu Ogińskim, Aleksandrze Michale Sapieże, Józefie Sylwestrze Sosnowskim, Ludwiku Skuminie Tyszkiewiczu oraz targowiczanach Szymonie Marcinie Kossakowskim i Józefie Zabielle. Co więcej - co do większości z tych hetmanów nie wiadomo, czy utrzymywali wyodrębnione biura - kancelarie wojskowe. W przypadku hetmanów, którzy objęli buławy po 1764 r. (w Koronie) i 1766 r. (na Litwie), wobec przejęcia pełni władzy nad armią najpierw przez Komisję Wojskową, a następnie przez Departament Wojskowy Rady Nieustającej, nie było ku temu odpowiednich przesłanek, jak i motywacji, gdyż praktycznie cała dokumentacja wojskowa przechodziła przez kancelarię tych organów kolegialnych. W przypadku hetmanów z nominacji królów z dynastii saskiej wydaje się, że na ich dworach istniały przynajmniej namiastki kancelarii hetmańskich. Jednak całkowicie nieznane są losy spuścizn po Stanisławie Chomentowskim, Michale Józefie Massalskim i Stanisławie Michale Denhoffie (jakieś dokumenty po nim wdowa zdeponowała w klasztorze jasnogórskim). W przypadku papierów wojskowych Wiśniowieckiego można domniemywać, że były stosunkowo nieliczne i poszły w rozsypkę w trakcie kolejnych podziałów całej schedy między jego córki i wnuczki ${ }^{50}$. Zapewne tylko nieliczna dokumentacja wojskowa przechodziła przez dwór

${ }^{46} \mathrm{~W}$ nim spuścizna po J. Potockim jako hetmanie, to bez wątpienia AGAD, APPot, nr 59, 60, $127-129$.

47 AGAD, ARos, M, pudło 3; AGAD, ARos, K, Supl., nr 27; AGAD, Zbiór Anny Branickiej, dz. I: Kancelaria Hetmańska, nr 35-40, 634, 1382, 1394, 1528-1535, 1615, 1721, 1722, 1736, 1805, 1950, 1952, 2138, 2145, 2221-2225, 2297, 2441, dz. II: Akta różnej proweniencji, nr 480.

${ }^{48}$ K. Syta, Archiwa magnackie..., s. 181.

49 Wyliczone prze K. Sytę jednostki nie są pozostałością archiwum hetmańskiego F.K. Branickiego, K. Syta, Materiaty do przewodnika..., s. 113.

${ }^{50}$ Pokrótce o losach spuścizny po M.S. Wiśniowieckim, K. Syta, Archiwa magnackie.., s. 250. 
Aleksandra Michała Sapiehy i współcześnie jej szczątków należy poszukiwać w spuściźnie sapieżyńskiej przechowywanej głównie w Bibliotece Litewskiej Akademii Nauk im. Wróblewskich (Lietuvos mokslų akademijos Vrublevskių biblioteka) w Wilnie ${ }^{51}$. O kancelarii wojskowej Michała Kazimierza Ogińskiego wiadomo, że została zagarnięta przez Rosjan pod Stołowiczami we wrześniu 1771 r. i prawdopodobnie uległa zniszczeniu ${ }^{52}$. Jej szczątków nie sposób się doszukać w spuściźnie archiwalnej po osiemnastowiecznych Ogińskich, która tworzy zasadniczy zrąb zespołu numer 12 („Дела о Польше и Литве”) w Rosyjskim Państwowym Archiwum Akt Dawnych w Moskwie. Stosunkowo najwięcej informacji zachowało się o kancelarii hetmańskiej Ludwika Konstantego Pocieja, którą w drugiej dekadzie XVIII w. nadzorował starosta starodubowski, podkoniuszy litewskich i pisarz wojsk litewski Jan Biegański, jednocześnie regent kancelarii wojska litewskiego. Sporządził on najpóźniej w 1720 r. rejestr dokumentów i akt znajdujących się w archiwum Pocieja. Wśród nich były asygnaty i rozliczenia pensji hetmańskiej, dokumenty finansowe wojska litewskiego związane przede wszystkim z zakupem mundurów i innego wyposażenia, raporty o stanie oddziałów tudzież akta sądów hetmańskich ${ }^{53}$. Jeżeli pominąć regulaminy organizacyjne i kalkulacje finansowe oblatowane w księgach komisji skarbowo-wojskowych i trybunałów skarbowych, to do dnia dzisiejszego $\mathrm{z}$ archiwum hetmańskiego Pocieja zachowały się jedynie pojedyncze dokumenty w Archiwum Roskim i może w Archiwum Radziwiłłowskim ${ }^{54}$.

\section{CHARAKTERYSTYKA ARCHIWÓW HETMAŃSKICH}

Analiza zasobów zachowanych archiwów hetmańskich wskazuje na znaczny w stosunku do poprzedniego stulecia wzrost ilościowy dokumentacji wojskowej przechodzącej w XVIII w. przez biura - kancelarie hetmańskie ${ }^{55}$. Nie wynikało to jednak ani z nowych regulacji prawnych, gdyż tych w tej kwestii nie było, ani z większej troski o stan armii ze strony osób dzierżących buławy. Zgodne było natomiast z założeniami rodzącej się wówczas w Europie biurokracji rozumianej

${ }^{51}$ Przede wszystkim w zespole (fondas) 139, ale też w zespołach 7, 9, 16, 17, 18, 21. Omówienie krótkie zasobów archiwaliów sapieżyńskich w Wilnie: A. Rachuba, Archiwa Sapiehów - ich losy, stan obecny, „Miscellanea Historico-Archivistica” 1998, t. IX, s. 105; L. Olechnowicz, Archiwa rodowe i osobiste w Litewskim Państwowym Archiwum Historycznym, „Miscellanea Historico-Archivistica", t. IX, s. 153.

${ }^{52}$ W. Konopczyński, Konfederacja barska, t. 2, Warszawa 1991, s. 541-552; J. Michalski, Ogiński Michat Kazimierz, Polski Stownik Biograficzny, t. XXIII, Wrocław i in. 1978, s. 626.

${ }^{53}$ C. Szadkowska, Ludwik Konstanty Pociej..., s. 78-86.

${ }^{54}$ AGAD, AR, dz. VII, nr 241-243; AGAD, ARos, M, pudło 1; C. Szadkowska, op.cit., s. 81.

55 K. Syta, Archiwa magnackie..., s. 179. 
jako przerost formalistyki w działaniu urzędu, a służyło podkreśleniu znaczenia i powagi władzy hetmańskiej. Doszło do sytuacji nieco paradoksalnej, w której coraz gorszej kondycji armii Rzeczypospolitej, wynikającej w dużej mierze z fatalnego administrowania nimi przez hetmanów, towarzyszył rozrost form kancelaryjnych, jak i znaczący przyrost ilości znajdującej się w obiegu dokumentacji wojskowej. W dużej mierze sprawcami tego byli sami hetmani, który powołując się tak na swoje rzeczywiste, jak i uzurpowane prerogatywy, domagali się od podkomendnych nie tylko składania raportów i meldunków, ale też narzucali im konieczność uzyskania akceptacji lub choćby opinii hetmańskiej w niemal każdym aspekcie życia wojskowego. W konsekwencji w spuściznach po osobach dzierżących buławy w XVIII w. zachowała się dokumentacja wojskowa bardzo różnorodna pod względem formalnym, kancelaryjnym i merytorycznym, przy czym ilościowo dominuje korespondencja, a najrzadsze, choć niezwykle wartościowe, są dokumenty o charakterze normatywnym. Przede wszystkim brakuje wśród nich najważniejszych aktów, które hetmani powinni byli wydać, jeżeli myśleli o uzdrowieniu armii Rzeczypospolitej, czyli regulaminów tak ogólnowojskowych, jak też szczegółowych, regulujących zasady dyscypliny, wyszkolenia czy pełnienia służby w określonych warunkach. Powód jest jasny - żaden z osiemnastowiecznych hetmanów koronnych i litewskich takich aktów normatywnych nie wydał, choć obligowały ich do tego ustawy sejmu niemego, deklaracje trybunałów skarbowych, a przede wszystkim opracowane w latach 1717-1719 i zatwierdzone mocą władzy buławy regulaminy organizacyjne regimentów autoramentu cudzoziemskiego ${ }^{56}$. W kolejnych dekadach pojawiały się zapowiedzi ich wydania, a hetman polny Wacław Rzewuski w drugiej połowie lat 50. i na początku lat 60. XVIII w. czy to zlecił, czy też jedynie stworzył Samuelowi Brodowskiemu warunki do pracy nad regulaminami ogólnowojskowymi. Jednak finalnym tego produktem były nigdy niezatwierdzone przez hetmanów, jak i niewykorzystywane w wojsku regulaminy studyjne, których rękopiśmienne wersje robocze, a w przypadku regulaminu dla piechoty - dopracowany projekt, spoczęły w archiwum wojskowym Rzewuskich ${ }^{57}$. Są one jedynie ciekawym przyczynkiem do oceny (nie)skuteczności osiemnastowiecznych hetmanów koronnych w zakresie zarządzania wojskiem, tak jak i różnego rodzaju regulaminy wojskowe groma-

${ }^{56}$ T. Ciesielski, Armia koronna..., s. 280-217; idem, Samuel Brodowski - kodyfikator prawa wojskowego w czasach panowania Augusta III, [w:] E. Kozerska, M. Maciejewski, P. Stec (red.), Historia testis temporum, lux veritatis, vita memoriae, nuntia vetustatis. Ksiega jubileuszowa dedykowana Profesorowi Włodzimierzowi Kaczorowskiemu, Opole 2015, s. 399-400.

${ }_{57}$ ANKr, Archiwum Podhoreckie APodh, I, nr 119, 120, 121, 122, 123 i 124; APodh, II, nr 8, 32, 38, 39, 52, 70, 154, 171, 172, 175, 183, 186, 229, 250, 251; T. Ciesielski, Samuel Brodowski..., s. $411-413$. 
dzone w kancelariach hetmańskich ${ }^{58}$. Jeżeli chodzi o realne działania, mające na celu uporządkowanie kwestii prawnego funkcjonowania wojska i jego wyszkolenia, to hetmanów koronnych zdecydowanie przerośli ich litewscy koledzy, a konkretnie - M.K. Radziwiłł, który jeszcze jako hetman polny opracował regulamin musztry dla regimentu pieszego buławy polnej, a w 1746 jako hetman wielki wydał krótki „regulamin” opisujący obowiązki towarzyszy zaciągu narodowego, zaś w odniesieniu do całego wojska - zasady zachowania oddziałów na kwaterach i w trakcie marszu ${ }^{59}$.

Znacznie chętniej hetmani wydawali lub zatwierdzali regulaminy organizacyjne oddziałów autoramentu cudzoziemskiego ${ }^{60}$. W spuściznach po kancelariach hetmańskich zachował się cały szereg tzw. regulamentów, począwszy od wydawanych przez A.M. Sieniawskiego i L.K. Pocieja jeszcze przed $1717 \mathrm{r}^{61}$ Kolejne, dostosowane do uchwał sejmu niemego, zostały przez tych hetmanów zatwierdzone w 1717 r. i w latach następnych, z tym zastrzeżeniem, że część z nich miała charakter skrócony do podania jedynie nowej struktury organizacyjnej sztabów i kompanii, a niekiedy nawet tylko pojedynczych pododdziałów wchodzących w skład regimentów ${ }^{62}$. Cześć regulamentów została w obu armiach Rzeczypospolitej zweryfikowana w latach 30.-50. XVIII w., przy czym cały czas odwoływano się do regulaminów organizacyjnych ustanowionych w 1717 r., przykładem: regulaminy opracowane i zatwierdzone przez M.S. Wiśniowieckiego i M.K. Radzi-

58 AGAD, ARos, M, pudło 2.

59 „Compendium Reglementu do Exercerunku Pieszego u Regimentu JKMci Konnego Buławy Polnej WXLitt. 1744”, РНБ, ф. 957, Pol. O IX, nr 3; „Exercition Buch auß Regiment Infanteri”, 16 VI 1736, AGAD, AR, dz. VII, k. 49-61; S. Kutrzeba, Polskie ustawy i artykuły wojskowe od XV do XVIII wieku, Kraków 1937, s. 299-301. Pomijam sprawczą rolę Radziwiłła w wydaniu w 1754 r. zbioru praw wojskowych zatytułowanego „Artykuły wojenne powagą Rzpltey, królów polskich y hetmanów W. X. Lit. różnymi czasy ustanowione, teraz zaś z rozkazu JO. Xiążęcia Jegomości Michała V. Kazimierza Radziwiłła wojewody Wileńskiego, hetmana W. X. Lit. przedrukowane...”, T. Ciesielski, Michat Kazimierz Radziwitł..., s. 309, 312-318.

${ }^{60} \mathrm{~K}$. Syta zaliczył regulaminy do dokumentacji określonej przez niego jako „administracyjna” lub „wojskowa”, K. Syta, Dokumentacja wojskowa..., s. 53-60; idem, Archiwa hetmanów koronnych..., s. 77-90.

${ }^{61}$ Lietuvos Valstybès Istorijos Archyvas, Vilnius (LVIA), SA 4274, k. 353-354; SA 13681, k. 5-6v, 27-28, 56v-57, T. Ciesielski, Wojsko litewskie w latach 1698-1709, [w:] B. Dybaś (red.), Wojny pótnocne w XVI-XVIII wieku. W czterechsetlecie bitwy pod Kircholmem, Toruń 2007, s. 165-182; A. Sowa, Pociej Ludwik..., s. 42.

${ }^{62}$ BCZ, 2648; ANKr, APodh, I, nr 93; APodh, II, nr 254 (memoriał krytykujący projekty regulaminów organizacyjnych z 1717 r.), 256 (plan reorganizacji wojska), 263; APodh, III (określane też jako Teki Andrzeja Potockiego - cytowane dalej APodh, III), pudło VI 6/1; LVIA, SA 18581, k. 28; SA 18259, k. 22-23, 39-43; V. Rakutis, Lietuvos kariuomenés organizacija reglamentuojantys dokumentai 1717-1775 m., „Karo archyvas”, t. XVIII, Vilnius 2003, s. 80-82; T. Ciesielski, Armia Wielkiego..., s. 74, 81. 
wiłła w armii litewskiej ${ }^{63}$. W Koronie z możliwości uporządkowania spraw związanych z organizacją wszystkich oddziałów autoramentu cudzoziemskiego nie skorzystał J. Potocki, choć w 1737 r. i 1744 r. mógł się oprzeć na decyzjach Trybunału Skarbowego w Radomiu. Dopiero wiosną 1746 r. polecił komendantom regimentów, aby zastosowali się do „pozwu” trybunalskiego z 1744 r. i rozesłał im podpisane przez siebie „regulaminy” organizacyjne. Jednak blisko dwuletnia zwłoka zadecydowała o fiasku akcji zrewidowania struktur organizacyjnych oddziałów autoramentu cudzoziemskiego ${ }^{64}$. W rezultacie dopiero w latach 50. XVIII w. w niektórych regimentach wprowadzono nowe regulaminy organizacyjne, niekiedy bardzo szczegółowe - poruszające kwestie kancelaryjne czy wyposażenia i wyszkolenia, jak w przypadku regimentu pieszego królewicza i oddziałów noszących miano buławy polnej Wacława Rzewuskiego ${ }^{65}$.

Regulaminy organizacyjne były dokumentami o jednoznacznym charakterze publicznym i to także wówczas, gdy dotyczyły regimentów pieszych i dragońskich obu buław. Należały do podstawowej dokumentacji wojskowej opracowywanej i gromadzonej w kancelariach hetmanów w związku ze sprawowaną przez nich władzą administracyjną nad wojskiem - tak jak raporty przedstawiające stany osobowe, uzbrojenie i wyposażenie oddziałów. Ten rodzaj dokumentacji znaleźć można we wszystkich zachowanych spuściznach po hetmanach Rzeczypospolitej z lat $1704-1794^{66}$. W archiwach A.M. Sieniawskiego i S.M. Rzewuskiego napotkać można przy tym zarówno tabele stanów i wykazy wyposażenia oddziałów nawiązujące do prowadzonych w XVII w., a nawet pod koniec XVI w., jak też raporty miesięczne sporządzone według nowych formularzy, opracowanych zapewne na wzór saski ${ }^{67}$. Te ostatnie stały się podstawą sprawozdawczości w obu armiach Rzeczypospolitej po 1717 r., a stanowiły o tym regulaminy organizacyjne regimentów nakazujące szefom, pułkownikom lub wyznaczonym przez nim oficerom sztabowym, aby sporządzali znormalizowane w skali całego autoramentu cudzoziemskiego „tabele, rejestry miesięczne i ekstrakty do nich należące”, które

${ }^{63}$ AGAD, AR, dz. VII, nr 2, k. 4-13, 32-33, 42-48, 53, 54; ANKr, APodh, II, nr 363; LVIA, SA 18259, k. 7-10, 26-28, 48-54, 55-62, 67-69; V. Rakutis, Lietuvos kariuomenès..., s. 95-100; T. Ciesielski, Armia Wielkiego..., s. 73-85; idem, Michat Kazimierz Radziwitł..., s. 308-309.

${ }^{64}$ AGAD, ARos, M, pudło 3; AGAD, APPot, s. 448-451, 667-668; Львівска Наукова Бібліотека НАН України ім. В.Стефаника (ЛНБ), fond 145, 20, k. 104-v; J. Potocki do W. Puchalskiego, Załoźce 17 IV 1746, AGAD, Zbiór Anny Branickiej, I Kancelaria Hetmańska, nr 2848; T. Ciesielski, Armia koronna ..., s. 211-212.

${ }_{65}$ AGAD, ARos, M, pudło 6; ANKr, APodh, II, nr 229, 250; APodh, III, pudło V 1/6, pudło VI 3/1; APodh, IV, pudło III 6, pudło IV, pudło LV 12.

${ }^{66} \mathrm{~K}$. Syta zaliczył raporty do dokumentacji określonej przez niego jako ,administracyjna” lub „wojskowa”, K. Syta, Dokumentacja wojskowa..., s. 53-60; idem, Archiwa hetmanów koronnych..., s. $77-90$.

${ }^{67}$ BCZ, nr 2639, 2648. 
ostatniego dnia każdego miesiąca miały być przesyłane „wespół z ekstraktami ubytku i przybytku ludzi, królowi, hetmanowi, szefowi wojska cudzoziemskiego zaciągu oraz inspektorowi wojskowemu (...) dla informacji wiele jest żołnierzy znajdujących się w gotowości służby, ale też i na pokazanie pieczołowitości około konserwacji każdego w ogólności i szczególności” ${ }^{\prime 68}$. Co więcej - stanowiły one podstawę do sporządzania tabel kwartalnych na potrzeby rozliczenia i lustracji regimentów dokonywanych corocznie przez komisarzy wojewódzkich na trybunały skarbowe, jak też do weryfikacji stanów oddziałów w trakcie ich okresowych przeglądów przeprowadzanych przez generałów inspektorów. Schematy raportów miesięcznych kilkakrotnie uległy modyfikacji pomiędzy trzecim a siódmym dziesięcioleciem XVIII w. (m.in. większy nacisk położono na umieszczanie w nich informacji o ruchach kadrowych, urlopach i czasowych ubytkach stanów oddziałów spowodowanych chorobami czy karami aresztu ${ }^{69}$, a przede wszystkim ich składanie zaczęło być skrupulatnie egzekwowane przez kolejnych hetmanów, jak i regimentarzy generalnych. Z okresu dowodzenia armią koronną i litewską przez Stanisława Poniatowskiego, Józefa Potockiego i Michała Serwacego Wiśniowieckiego zachowały się jedynie pojedyncze raporty o stanie oddziałów, ale z korespondencji prowadzonej z szefami i komendantami regimentów wynika, że dwaj ostatni starali się wyegzekwować od podwładnych w miarę regularne przesyłanie „tabel miesięcznych”70. Kolejni hetmani wielcy: koronny J.K. Branicki i litewski M.K. Radziwiłł, nie tylko egzekwowali obowiązek składania comiesięcznych raportów, ale też zadbali o ich przechowywanie w swoich kancelariach - biurach wojskowych ${ }^{71}$. Co więcej: obowiązek składania raportów o stanie osobowym rozciągnęli na komendantów twierdz i garnizonów, a także na dowódców chorągwi zaciągu narodowego, jak i utworzonych z nich komend wojskowych i partii ${ }^{72}$. Praktykę tę kontynuowali Wacław Rzewuski w trakcie krótkiego dzierżenia buławy wielkiej na przełomie 1733 i 1774 r. oraz jego syn Seweryn, gdy jako het-

68 „Objaśnieniu Regulaminu Wojska Pieszego Koronnego Anni 1717”, ANKr, APodh, II, nr 263. Podobne zapisy znaleźć można w innych regulaminach organizacyjnych oddziałów autoramentu cudzoziemskiego z 1717 oraz w opracowanym dla regimentu pieszego królewicza armii koronnej w latach 50. XVIII w., AGAD, ARos, M, pudło 6.

${ }^{69}$ K. Granowski do J.K. Branickiego, Warszawa 25 IX 1759, AGAD, ARos, K, pudło VII, nr 29, s. 86; Regulamen Generalny Regimentu Pieszego Najjaśniejszej Królowej Jej Mci, AGAD, ARos, M, pudło 6.

70 AGAD, ARP, 362; AGAD, AR, dz. VII, nr 89-92, 97, 98, 100, 101, 103, a także raporty z lat 30. i początku 40. o stanie niektórych chorągwi zaciągu narodowego, $\mathrm{nr}$ 128, 129, 150, 159, 161, 162, 170-172, 175, 180-183, 187.

${ }^{71}$ AGAD, ARos, M, pudła 5-11, 13-18; AGAD, Braniccy z Suchej, nr 68/85; AGAD, AR, dz. VII, 93-126.

${ }_{72}$ AGAD, ARos, M, pudła 19-22, pojedyncze raporty w AGAD, ARos, M, pudła 1 i 2; AGAD, AR, dz. VII, 127-136, 138-168, 170, 172-216, 218, 244-249, 252-254, 257, 258. 
man polny obejmował kierownictwo nad Departamentem Wojskowym ${ }^{73}$. Oprócz tabel miesięcznych od połowy XVIII w. hetmani wymagali od szefów regimentów składania okresowych raportów o stanie osobowym rozbudowanych o tzw. stammlisty, conduitlisty i lenunglisty, czyli spisy oficerów, okazjonalnie podoficerów, powiększone o informacje o pobieranym wynagrodzeniu oraz o przebiegu służby z podaniem dat awansu na kolejne stopnie oraz starszeństwa w regimencie. W latach 50. i 60. XVIII w. tylko w nielicznych wykazach oficerskich podawano informacje o narodowości, pochodzeniu społecznym, wyznaniu i wykształceniu, co w kolejnych dziesięcioleciach stało się standardem ${ }^{74}$. Najbardziej rozbudowane tak merytorycznie, jak i ilościowo były raporty związane z oddziałami noszącymi miano hetmańskich. Obok ,tabel miesięcznych” (dla regimentów J.K. Branickiego, M.K. Radziwiłła i W. Rzewuskiego z lat 40., 50. i początku 60. XVIII w. zachowanych niemal w komplecie) bardzo wiele jest tzw. likwidacji oddziałów, przygotowywanych na trybunały skarbowe, ksiąg-dzienników raportów z pełnienia służby w garnizonach, czy dzienników-protokołów czynności sądowych podejmowanych w oddziałach. Część dokumentacji powstawała przy tym na wyraźne polecenie hetmanów, czego dowodzą zachowane w spuściznach ich rozkazy, dyspozycje itp. ${ }^{75} \mathrm{~W}$ archiwum Wacława Rzewuskiego zachowały się też raporty składane mu przez oddziały wchodzące w skład garnizonu kamienieckiego w latach 1733-1735 jako komendantowi fortec pogranicznych, a w latach 1763-1765 jako hetmanowi polnemu, dowodzącemu wojskiem na pograniczu południowo-wschodnim ${ }^{76}$. Natomiast Seweryn Rzewuski zgromadził raporty o stanie garnizonów warszawskiego, kamienieckiego oraz szeregu oddziałów armii koronnych, tak chorągwi i regimentów, jak też pułków, brygad i dywizji z lat 1774-1775, $1777-1780$ i $1792-1794^{77}$.

W regulaminie regimentu pieszego królowej z lat 50. XVIII w. pojawił się zapis zobowiązujący do przesyłania hetmanowi wyciągów $\mathrm{z}$ wydanych $\mathrm{w}$ okresie raportowym rozkazów. Jednak w zachowanych spuściznach po kancelariach hetmańskich z początków drugiej połowy XVIII w. zachowały się tylko nieliczne raporty tego typu, przy tym niemal wszystkie - z regimentów pozostających pod

${ }^{73}$ ANKr, APodh, APodh, III, pudło VI 3/1-22, pudła VII-IX. W pudle VII zachowały się też pojedyncze raporty różnych oddziałów koronnych i garnizonu kamienieckiego z lat 50. i 60.

${ }^{74}$ AGAD, ARos, pudło 5, 6, 9, 13; ANKr, APodh, II, 83; APodh, III, pudło IV 1/225, 2/26, pudło V 1/5, 57, 109, 110, 119,132, 137, 148, 166, 167, 190, pudło VI 1/16, 20, 21, 54, 58, 91, 128, 141, 165; APodh, IV, pudło III 102 i 104, pudło XXVI 19, pudło XXXVI 2526.

75 AGAD, ARos, M, pudło 10, 11, 14; AGAD, AR, dz. VII, 104-126, 171-256; ANKr, APodh, I, nr 134, 135, 136, 137, 138, 139; APodh, II, nr 28, 61, 67, 83, 106, 122, 229, 253, 268; APodh, III, pudło I 1/1-57, pudła IV-VI; APodh, IV pudła III, XXII, XXVI, XXXV, XXXVII, XL, XLIV, XLVII, L, LV; BCz, 2643, 2648, 2652, 3115.

${ }^{76}$ ANKr, APodh, II, 49, 361; TAP, pudło VI 3/2; APodh, IV, pudło II.

77 ANKr, APodh, III, pudło V 2/1-25, pudło VII 1/25-94, pudło VIII. 
bezpośrednią komendą osób dzierżących buławy. Częste natomiast są oryginały lub kopie ordynansów i uniwersałów wydawanych przez króla, hetmanów, regimentarzy i inne osoby pełniące funkcje wojskowe, które dotyczyły tak całych armii, jak i oddziałów bezpośrednio podlegających hetmanom ${ }^{78}$. Na szczególną uwagę zasługują zwłaszcza uniwersały i rozkazy porządkujące sprawy armii. Przykładowo: J. Potocki kilkakrotnie próbował zdyscyplinować kadrę oficerską i zmusić ją do pełnienia czynnej służby, wydając stosowne rozkazy, tak napominające, jak i grożące wprowadzeniem różnego typu sankcji, wstrzymaniem wypłaty żołdu czy usunięciem z armii. Co więcej: $\mathrm{z}$ kancelarii wojskowej Potockiego wychodziły pozwy przeciwko oficerom uchylającym się od pełnienia czynnej służby - do sądów regimentarskich i hetmańskich ${ }^{79}$. Podobne działania, i z takim samym skutkiem, podejmowali M.K. Radziwiłł i J.K. Branicki, choć ten ostatni na dobrą sprawę - dopiero po śmierci Augusta III $^{80}$. Znacznie skuteczniejsze były działania hetmańskie związane $\mathrm{z}$ kreowaniem oddanego sobie, lojalnego korpusu oficerskiego w obu autoramentach, które zaobserwować można już pod koniec lat dwudziestych XVIII w., a zintensyfikowane zostały w okresie dzierżenia buławy wielkiej koronnej przez Potockiego i Branickiego. Zręcznie omijali oni nałożony na hetmanów przez uchwały sejmu niemego obowiązek zadbania, aby obcokrajowców i dysydentów nie było więcej niż rodowitej szlachty i katolików. Przede wszystkim jednak starali się obejść prerogatywy monarchy, jakimi było wyłączne prawo mianowania rotmistrzów w zaciągu narodowym oraz szefów i oficerów sztabowych - czyli od podpułkownika względnie majora wzwyż w autoramencie cudzoziemskim. Co więcej: skutecznie ograniczali swobodę rotmistrzów i szefów w obsadzaniu stanowisk poruczników i chorążych w chorągwiach zaciągu narodowego oraz wszystkich oficerskich - do stopnia majora - w autoramencie cudzoziemskich. Hetmani umiejętnie wykorzystywali swoje uprawnienia, a przede wszystkim wyłączność na wydawanie

78 Jako przykład mogą służyć kopiariusze sporządzone w kancelarii wojskowej M.K. Radziwiłła - AGAD, AR, dz. VII, 1 a-d, 2, 3 a-c. Ordynanse i rozkazy Sieniawskiego, BCz, nr 2565. W przypadku J.K. Branickiego odpisy jego uniwersałów i rozkazów w AGAD, ARos, K, Supl. 4-22; AGAD, ARos, M. pudła 2-22; AGAD, ZAB, nr 506, 509 może też AGAD, Zbiór Popielów, nr 167 (jednostka zawiera kopie uniwersałów Branickiego z lat 50. i królewskich z lat 40. XVIII w.). Rozkazy Wacława Rzewuskiego, ale kierowane tylko do swoich oddziałów, ANKr, APodh, II, 131. Przemieszane rozkazy dwóch Rzewuskich, Wacława i Seweryna, a także A.M. Sieniawskiego i J.K. Branickiego, ANKr, APodh, II, 111, 230. Kopiariusze ordynansów wychodzących z kancelarii Seweryna Rzewuskiego w latach 1774-1775 i 1793, ANKr, APodh, II, nr 19, 365; pudło X 1.

${ }^{79}$ Korespondencja z 1736 r. w AGAD, ARos, M, pudło 3; Stanisławów 15 X 1736, 28 V 1738 i 19 IV 1739, Załoźce, 20 XI 1737, Lietuvos Mokslų Akademijos Biblioteka, Vilnius, fondas 273, 1970-1972; Pików 24 i 25 VII 1738, Biblioteka Uniwersytetu Warszawskiego, 97, s. 143, 291; Pocсийский Государственный Архив Древних Актов, Москва, fond 12, nr 88, s. 54.

${ }^{80}$ Wojewódzka Biblioteka Publiczna im. H. Łopacińskiego w Lublinie, nr 1008; Biblioteka Naukowa Polskiej Akademii Umiejętności i Polskiej Akademii Nauk w Krakowie, nr 1132, k. 27v-28; Archiwum Państwowe w Poznaniu, Akta Antoniego Kossowskiego, nr 9. 
rozkazów forsztelacyjnych, bez których oficer awansowany czy to przez króla, czy też przez swoich bezpośrednich przełożonych, nie mógł się posługiwać się w życiu wojskowym uzyskanym stopniem ${ }^{81}$. Innym środkiem oddziaływania na armię było prawo mianowania komendantów fortec oraz regimentarzy, czyli dowódców wydzielonych zgrupowania wojska, tzw. partii (w literaturze przedmiotu nazywanych też dywizjami). Co prawda, takie decyzje powinny były być konsultowane $\mathrm{z}$ dworem królewskim, ale z reguły hetmani dokonywali samodzielnych wyborów regimentarzy i to najczęściej ze swojego kręgu klientalnego, a nawet rodzinnego. Tego stanu rzeczy nie zmieniły zapisy w akcie konfederacji przyjętym na sejmie konwokacyjnym w 1733 r., następnie zatwierdzone na sejmie pacyfikacyjnym w 1736 r., zakazujące hetmanom przekazywania według własnego uznania innym osobom komendy generalnej nad autoramentem cudzoziemskim ${ }^{82}$. Dobitnie tego dowodzą fakty powierzania przez Józefa Potockiego pod koniec lat 30. XVIII w. dowództwa nad zgrupowaniami wojskowymi składającymi się z oddziałów obu autoramentów oficerom, którym nadawano tytuł regimentarza generalnego. Jednym z nich został w 1738 r., i to z pełnią władzy nad wojskiem, syn hetmana, wojewoda smoleński Stanisław Potocki ${ }^{83}$.

Po 1717 r. zmieniła się struktura i ilość przechodzącej przez kancelarie hetmańskie dokumentacji finansowej odnoszącej się do utrzymania całego wojska. Jak słusznie zauważył K. Syta ${ }^{84}$ - najliczniej występuje ona w archiwum Adama Mikołaja Sieniawskiego, a tworzyły ją akta komisji hibernowych, dyspozycji i dystrybucji hibern, zestawienia wydatków na wojsko ujmujące kwartę i hibernę, a także skwitowania oddziałów wojsk koronnych z pieniędzy pobranych tytułem żołdu, lenungów czy hiberny ${ }^{85}$. Elementem takiej dokumentacji były też komputy wojska, o ile pojawiały się w nich kwoty przeznaczone na utrzymanie armii, rodzajów wojska i poszczególnych oddziałów. Jeszcze na początku XVIII w. podlegały one częstym zmianom, czego dowodzą zachowane w spuściźnie po Sieniawskim zestawienia komputów wojska koronnego od objęcia przez niego urzędu hetmańskiego ${ }^{86}$. W 1717 r. ustanowiono jednak stały komput, który nie uległ zmianie przez następnych blisko 60 lat, tak jak określone w nim źródła finansowania poszczególnych oddziałów tworzących obie armie Rzeczypospoli-

${ }^{81}$ Rozkazy forsztelacyjne można znaleźć w praktycznie wszystkich jednostkach wyliczonych w przypisie 59. Ponadto AGAD, ARos, M, pudła 2 i 3; AGAD, AR, dz. VII, nr 72, 73, 74; ANKr, APodh, IV, pudło X 11.

${ }^{82}$ VL, t. 6, s. 290-291.

${ }^{83}$ AGAD, ARos, M, pudło 3.

${ }^{84}$ Dokumentacja finansowa omówiona, K. Syta, Dokumentacja wojskowa..., s. 60-61; idem, Archiwa hetmanów koronnych..., s. 91-94.

${ }^{85} \mathrm{BCz}, \mathrm{nr} 1684,2470,2558,2565,2590,2591,2607,2636,2639-2642,2671 / 1-9,2674 / 2-3$, 2700,3115 .

${ }^{86}$ AGAD, AR, dz. VII, nr 81; ANKr, APodh, II, nr 49; BCz, nr 2589 (komputy też w nr 2700). 
tej. Dlatego też choć w spuściznach hetmańskich można znaleźć wiele odpisów komputów koronnego i litewskiego sporządzonych w latach 1717-1775, to nabierają one wartości poznawczej jedynie wtedy, gdy zawierają informacje personalne o kadrze dowódczej i oficerskiej ${ }^{87}$. Dużą wartość mają też odpisy wykazów likwidacyjnych oddziałów przed trybunałami skarbowymi ${ }^{88}$. Odebranie uchwałami sejmu niemego hetmanom tzw. władzy pióra sprawiło ponadto, że ich realny wpływ na sprawy finansowania armii Rzeczypospolitej sprowadził się do dysponowania funduszami largicyjnymi wynoszącymi po $100000 \mathrm{zł}$ w Koronie i na Litwie. Swoboda w corocznym rozdzielaniu tych środków została hetmanom przy tym ograniczona przez wprowadzenie stałych wydatków planowanych na urzędników, dygnitarzy państwowych i wojskowych oraz na kancelarie wojskowe. W konsekwencji pozostawało mniej niż 50000 zł do rozdania między ,postrzelanych, straconych officyalistów y towarzystwo zasłużone" ${ }^{89}$, ale w praktyce czasu pokoju nagradzano zasłużonych oficerów i towarzyszy obu autoramentów. Wykorzystywane więc były do poprawy wizerunku hetmańskiego wśród żołnierzy. Dlatego też niekiedy konieczne było wyłożenie przez hetmana dodatkowo z prywatnych środków kilku, a nawet kilkudziesięciu tysięcy złotych ${ }^{90}$.

Drugą grupę stanowią akta finansowe oddziałów bezpośrednio podlegających hetmanom, które znaleźć można we wszystkich zachowanych spuściznach osiemnastowiecznych hetmanów: Adama Mikołaja Sieniawskiego, Stanisława Mateusza, Wacława i Seweryna Rzewuskich, Jana Klemensa Branickiego i Michała Kazimierza Radziwiłła. Tworzą ją księgi i akta luźne. Jeżeli chodzi o pierwsze są to przede wszystkim księgi rachunkowe $\mathrm{z}$ ujętymi dochodami i wydatkami regimentów oraz księgi wypłat żołdu i lenungów. Akta luźne to asygnacje dla hetmańskich oddziałów na wybranie należnych im pieniędzy (do 1717 r.), polecenia wyruszenia na tzw. egzakcję, czyli wybranie podatków z przydzielonych w uchwałach sejmu niemego oddziałowi starostw i dóbr, listy wypłat żołdu oraz zestawienie płac dla oficerów i żołnierzy, dokumentacja związana z zakupem wyposażenia, pokwitowania $z$ wypłaconych pieniędzy żołdowych i lenungowych, jak też korespondencja hetmanów z podwładnymi dotycząca spraw związanych z finansowaniem oddziałów ${ }^{91}$.

${ }^{87}$ AGAD, APPot, nr 60.

${ }^{88}$ ANKr, APodh, II, 74; APodh, III, pudło IX 1/39.

89 VL, t. 6, s. 140, 196.

${ }^{90}$ Rozdział funduszy largicyjnych w armii koronnej - 1727: APKr, APodh, I, nr 89 i APKr, APodh, II, nr 74; 1731: Централльный державний історичний архів України, м. Львів, f. 181, op. 2, 2323, k. 7-8; AGAD, ARP, 363; 1759: AGAD, ARos, M, pudło 21; T. Ciesielski, Armia koronna..., s. 48-50.

${ }^{91} \mathrm{BCz}, \mathrm{nr} 2527,2602,2606,2626,2639-2643,2645-2647,2652,2653,2675,2883,3115$; AGAD, ARP, 361, 363; ANKr, APodh, I, nr 81, 88, 89; APodh, II, nr 25, 36, 42, 64, 68, 81, 83, 89, 91, 118, 121, 145; APodh, III, pudła IV, V, VI; APodh, IV pudła XXII 4-9, XXXV, XXXVI, 
Dokumentacja finansowa, raporty o stanach osobowych i wyposażeniu, korespondencja służbowa związana z regimentami piechoty i dragonii, chorągwiami piechoty węgierskiej i janczarskiej, chorągwiami husarskimi, pancernymi lub petyhorskimi, a także pułkami jazdy lekkiej noszącymi miano jednej z buław, zdecydowanie góruje ilościowo nad analogicznymi aktami dotyczącymi innych oddziałów obu armii Rzeczypospolitej Obojga Narodów ${ }^{92}$. W swoim artykule K. Syta określił nawet dokumentację związaną z utrzymaniem finansowym oddziałów bezpośrednio podlegających hetmanom jako „bardziej osobistą" "93, a co więcej wydzielił ją wraz z listami żołnierskimi oraz dziennikami służby w odrębną grupę: „dokumentacja oddziałów hetmańskich"94. Trudno jednak się z tym zgodzić, gdyż w latach 1717-1775 takie regimenty i chorągwie praktycznie w całości utrzymywane były ze środków publicznych. Tylko sporadycznie hetmani pokrywali wydatki związane z wyposażeniem czy zaopatrzeniem oddziałów w żywność lub amunicję ze swoich prywatnych pieniędzy, a zdecydowanie częściej, niekiedy wręcz regularnie, przekazywali dodatkowe środki na utrzymanie nadkompletowych oficerów. Jednak - jak wynika z bliższej analizy trzeciej grupy akt finansowych, którą K. Syta nazwał „zabezpieczenie uposażenia urzędu hetmańskiego"95 - to Jan Klemens Branicki, Michał Kazimierz Radziwiłł czy Stanisław Mateusz i Wacław Rzewuscy wydzielali na żołd takich oficerów pieniądze ze swoich pensji hetmańskich. Dowodzą tego zachowane w ich spuściznach rozliczenia wydatkowania pensji, rozkazy dotyczące wynagrodzenia oficerów nadliczbowych, jak też i kwity wystawiane przez tych ostatnich jako potwierdzenie odebranego żołdu ${ }^{96}$. $\mathrm{O}$ wadze zaś przywiązywanej przez hetmanów do przyznanych im pensji świadczy dokumentacja związana z pobieraniem związanych z tym podatków.

Niewątpliwie tego typu dokumentacja administracyjna i finansowa, wytwarzana i gromadzona przez kancelarie wojskowe osób dzierżących w XVIII w. buławy, miała charakter publiczny, a w części wręcz nawet zasługiwała do zaliczenia

XL, XLIV, XLVII, L, LV, LVIII; AGAD, ARos, M, pudło nr 2, 10, 11, 14, 15; AGAD, ZAB, I KH, nr 2777-2779, 2781-2782; AGAD, Braniccy z Suchej, Supl. 59/1; AGAD, AR, dz. VII, nr 55, 65; AGAD, Braniccy z Suchej, Suplement 59/1; T. Ciesielski, Źródła do dziejów regimentów..., s. $84-87$.

92 Wystarczy zestawić zawartość pudeł z aktami regimentów pieszych i dragońskich J.K. Branickiego z innymi prowadzonymi dla poszczególnych regimentów, czy analogiczną dokumentację w spuściźnie po M.K. Radziwille (AGAD, AR, dz. VII, nr 4042, 45, 56, 59, 62, 63, 65 a-c, 66, 71).

${ }_{93}$ K. Syta, Dokumentacja wojskowa..., s. 60; Idem, Archiwa hetmanów koronnych..., s. 91-92.

${ }^{94}$ K. Syta, Dokumentacja wojskowa..., s. 63-65; idem, Archiwa hetmanów koronnych..., s. $98-101$.

${ }_{95}$ K. Syta, Dokumentacja wojskowa..., s. 60; Idem, Archiwa hetmanów koronnych..., s. 91-92.

96 AGAD, ARos, M, pudło 2, 10, 11; AGAD, ZAB, I KH, nr 467, 1400; BCz, nr 2624, 2640; ANKr, Podh, I, nr 88, 89; APodh, III, pudło III, pudło IX 1/20, pudło IX 3/46, pudło XI 1/5, 11 , pudło XII 18/3, 5; APodh, IV, pudła X i LV. 
jej, według dzisiejszej klasyfikacji, do akt tajnych o żywotnym znaczeniu dla interesów państwa, gdyż zawierała informację o rzeczywistej liczebności i wyposażeniu obu armii Rzeczypospolitej. Do tych samych kategorii należy zaliczyć akta, przede wszystkim korespondencję, powstałe w związku z prowadzeniem przez hetmanów zakazanych im w traktacie warszawskim działań dyplomatycznych i utrzymywaniem kontaktów z zagranicznymi organami władzy wojskowej oraz cywilnej ${ }^{97}$. Hetmani już od lat 20. XVIII w. utrzymywali stały kontakt korespondencyjny $z$ chanem krymskim i pogranicznymi urzędnikami osmańskimi - bejami oczakowskimi (sylistryjsko-oczakowskimi) oraz gubernatorami Benderu i Chocimia. Józef Potocki, po objęciu buławy wielkiej w 1735 r., korzystając z wybuchu wojny wschodniej (1736-1739), oficjalnie reaktywował hetmańską służbę dyplomatyczną, wysyłając posłów i rezydentów do chana krymskiego, hospodara mołdawskiego, dowódców wojsk rosyjskich oraz najważniejszych urzędników wojskowo-cywilnych Imperium Osmańskiego ${ }^{98}$. Jego wzorem inni hetmani, zwłaszcza Jan Klemens Branicki, utrzymywali kontakty dyplomatyczne z urzędnikami carskimi i orientalnymi, jak też innymi władcami europejskimi, m.in. z królami Francji i Prus ${ }^{99}$. Co więcej: odrodzenie dyplomacji hetmańskiej zaakceptowały najwyższe władze państwowe, o czym dobitnie świadczą uchwały rad senatu z lat 1739, 1752 i 1758 przyznające hetmanom zwrot kosztów poniesionych na działalność dyplomatyczną ${ }^{100}$.

Kolejnym wydzielonym rodzajem jest dokumentacja powstała przy wykonywaniu przez hetmanów władzy dyscyplinarnej i sądowniczej nad wojskiem ${ }^{101}$. Obowiązujące w obu armiach Rzeczypospolitej artykuły wojskowe (wojenne) i regulaminy przyznawały hetmanom bardzo rozległe kompetencje jurysdykcyjne, tak jeżeli chodzi o kategorię osądzanych spraw, jak i ferowanych wyroków ${ }^{102}$. Jeżeli chodzi o pierwsze, to władza hetmańska zaczynała się już od drobnych przestępstw przeciwko ludności cywilnej i naruszeniu dyscypliny wojskowej, jeżeli swoimi skutkami wychodziły poza obręb macierzystej jednostki żołnierzy.

${ }^{97}$ K. Syta, Dokumentacja wojskowa..., s. 62-63; Idem, Archiwa hetmanów koronnych..., s. $96-97$.

${ }_{98}$ AGAD, ARos, M, pudła 3 i 4; РНБ, ф. 957, nr Pol. IV 282; AGAD, ZAB, 2534; AGAD, Archiwum Przeździeckich, nr B 1197; AGAD, Sucha, Supl, 76, nr 283.

99 AGAD, ARos, K, Supl, nr 4-18 (a zwłaszcza 7/3 i 8/4); AGAD, ZAB, I KH, nr 982-993, 2773; AGAD, Braniccy z Suchej, Supl. nr 77; AGAD, AR, dz. II, ks. 51.

${ }^{100}$ BCz, nr 867, s. 58, 60, 66; BCz, nr 1696, k. 98, 100, 111; AGAD, Braniccy z Suchej, Supl., nr 77; AGAD, ARos, K, Supl., nr 14, k. 128-131; T. Ciesielski, Armia koronna ..., s. 134-140.

${ }^{101}$ Przez K. Sytę określona jako dokumentacja sądownicza, K. Syta, Dokumentacja wojskowa..., s. 61-62; idem, Archiwa hetmanów koronnych..., s. 94-96.

${ }^{102}$ Literatura poświęcona kompetencjom sądowniczym hetmanów na przestrzeni trzech wieków jest dość obszerna; autorami monografii i szeregu artykułów dotyczących XVI-XVII w. są Przemysław Gawron, Karol Łopatecki, Jan Sowa, a XVIII w. - Wojciech Organiściak. 
Hetmanom podlegało całe kilkustopniowe sądownictwo wojskowe, oddzielne dla obu autoramentów, jak też więzienia wojskowe (w Koronie znajdowały się tylko w Kamieńcu Podolskim i czasowo w Dubnie). Najniższą instancję sądową stanowiły $\mathrm{w}$ jeździe narodowego zaciągu sądy chorągwiane, a w autoramencie cudzoziemskim regimentowe sądy wojskowe (regimentowe krygzrechty) dla żołnierzy do stopnia kapitana włącznie, generalne sądy wojskowe (generalne krygzrechty) dla oficerów sztabowych oraz sądy garnizonowe. Sądami specjalnymi były standrechty (sądy nadzwyczajne zwoływane i ferujące wyroki w trybie pilnym, stosujące skróconą do maksimum procedurę), sądy neutralne (sądy polubowne rozpatrujące sprawy sporne między oficerami różnych regimentów) i tzw. ,iudicium compositum” (sądy polubowne w sprawach między żołnierzami a ludnością cywilną). Wyższymi instancjami w sądownictwie wojskowym były sądy regimentarskie i generalne krygzrechty odbywające się corocznie w maju w Radomiu. W przypadku sądów pierwszej instancji - hetmani posiadali prawo zatwierdzania wydanych wyroków, z możliwością zaostrzenia, jak i złagodzenia kary czy zastosowania prawa łaski. W przypadku sądów specjalnych i wyższych instancji - zwoływali je hetmani, którzy wyznaczali skład sędziowski ${ }^{103}$. Najwyższą instancję w sądownictwie wojskowym stanowiły sądy hetmańskie, które rozpatrywały apelacje od sądów wojskowych wszystkich szczebli, a w pierwszej instancji zajmowały się sprawami karnymi, podpadającymi pod kategorię „,wszelkie crimina laesae majestatis, rebellionis et conspirationis, potajemne z nieprzyjacielem Rzeczypospolitej korespondencje i ku onej szkodzie porozumienia się, fortec i zamków na zmowie poddanie, cekhauzów, magazynów, obozów zdradzenie, i nareszcie wszelkie nieposłuszeństwa hetmańskim ordynansom uczynkiem pokazane"104, a także postępowaniami o charakterze tak karnym, jak i rozjemczym, w których jedną ze stron byli najwyżsi oficerowie armii oraz dowódcy regimentów i chorągwi. Ponadto sądzeni byli w nich szpiedzy oraz żołnierze armii sprzymierzonych, którzy na terenach objętych jurysdykcją Rzeczypospolitej dopuścili się przestępstw kryminalnych. Wyroki sądów wojskowych miały szerokie spektrum: od upomnień i drobnych sankcji dyscyplinarnych przez wieloletnie i dożywotnie więzienie w ciężkich warunkach (tzw. przy taczkach) aż po kary śmierci wykonywane przez rozstrzelanie, powieszenie lub ścięcie. Zapadłe wyroki były ostateczne. „Od sądów hetmańskich apellacya nie idzie. Hetmani

${ }^{103}$ T. Ciesielski, Armia koronna..., s. 143-145; W. Organiściak, Środki prawne przeciwko wyrokom sądów wojskowych autoramentu cudzoziemskiego w Rzeczypospolitej szlacheckiej w sprawach karnych, „Problemy Prawa Karnego” 2004, t. XXV, s. 220-232; idem, Z badań nad postępowaniami szczególnymi w prawie karnym wojskowym Rzeczypospolitej szlacheckiej, „Problemy Prawa Karnego" 2000, t. XXIII, s. 117-129.

104 „Ordynacya sądów woyskowych wojsk koronnych cudzoziemskiego zaciągu za panowania Augusta III”, ANKr, APodh, IV, pudło X 2. 
$\mathrm{z}$ prawa dawnego polskiego mają merum imperium nad całym wojskiem et ius aggratiandi sine ulla appellatione" ${ }^{105}$. Zarówno rozległa władza, jak i rozbudowane sądownictwo wojskowe sprawiały, że o ile w okresie wojen powstawała stosunkowo niewielka ilość dokumentacji sądowniczej, to już w okresie pokoju ilość akt związanych z wykonywaniem przez hetmanów władzy jurysdykcyjnej lawinowo wręcz wzrastała. Dowodzą tego liczne akta spraw przesyłanych hetmanom do zatwierdzenia z sądów regimentarskich chorągwianych i regimentowych, jak też dokumentacja wytwarzana przez generalne krygzrechty i sądy hetmańskie. Dominują w nich protokoły posiedzeń sądów wraz z przesłuchaniem świadków i osób sądzonych (inkwizycje) oraz treścią ferowanych wyroków. Większość z nich opatrzona jest decyzjami podjętymi przez hetmanów, niekiedy wraz z prośbami osądzonych o złagodzenie wyroku. W przypadku sądów wyższej instancji i hetmańskich dochodzą do tego rozkazy hetmańskie powołujące sędziów spośród kadry oficerskiej armii i nakazujące przeprowadzenie śledztwa, a także pozwy i dekrety sądowe wraz ze stosownymi objaśnieniami, jeżeli były konieczne ${ }^{106}$. Należy przy tym podkreślić, że wszystkie wyroki ferowane przez sądy wojskowe miały pełną moc wykonawczą i nie podlegały uchyleniu przez władze i sądy cywilne, co dobitnie dowodzi, że nie była to dokumentacja o charakterze prywatnym, stanowiąca jedynie własność hetmanów. Taki sam charakter miały egzempty hetmańskie, zwalniające czasowo żołnierzy od obowiązku stawania przed sądami cywilnymi, których odpisy zachowały się w kopiariuszach sporządzanych w kancelariach osób dzierżących buławy ${ }^{107}$.

Takiego rozgraniczenia nie sposób prosto przeprowadzić w przypadku korespondencji, która stanowi jeżeli nie największą pod względem ilościowym, to znaczącą część zachowanych spuścizn hetmańskich. Spowodowane jest to kilkoma czynnikami. Po pierwsze: w trakcie porządkowania spuścizn cała korespondencja pozostała po hetmanach jako dowódcach wojskowych, urzędnikach i dygnitarzach cywilnych, przywódcach fakcji szlachecko-magnackich lub dużych grup klientalnych, właścicielach rozległych fortun magnackich, jak też ważnych osobach w swoich rodach, została zespolona i ułożona w ciągach alfabetyczno-chronologicznych. Sprawia to, że przemieszano respondentów cywilnych i wojskowych, a w obrębie listów jednej osoby: te o charakterze wojskowym z -

105 Ibidem.

106 AGAD, ARos, K, Supl., nr 4/1, 5, 6/1, 7/3, 13, 16; AGAD, ARos, M, pudła 3, 5-22; AGAD Braniccy z Suchej, nr 330/419 (niezwykle interesujące akta sądu nad Marcinem Lubomirskim), Supl., nr 77; AGAR, AR, dz. VII, nr 14-20 (w tym 18 a-e), 22-29, 31, 33, 34a; AGAD, Archiwum Zamoyskich, 3099; ANKr, APodh, II, nr 8 (s. 84-109), 28, 30, 61, 111; APodh, IV, pudło XXXV 98; BCz, nr 2633, 2635, 2598; BJ, nr 7594; CIM, s. 94, 96; J. Kamiński, Historia sądownictwa wojskowego w dawnej Polsce, Warszawa 1928, s. 91-99.

${ }_{107}$ AGAD, ARos, K, Supl., nr 4-20; AGAD, AR, dz. VII, 3 a, b, c. 
przykładowo - gospodarczymi, czy informacyjnymi ${ }^{108}$. Tymczasem w praktyce zarządzania dworami osób sprawujących urzędy hetmańskie często żołnierz, oficer regimentu lub chorągwi i to nie zawsze noszących miano buławy, mógł być agentem politycznym lub handlowym, administratorem dóbr, architektem zajmującym się tak budowlami, jak i ogrodami, preceptorem dzieci itp. Duża grupa wojskowych zaliczała się przy tym do członków fakcji szlachecko-magnackich lub grup klientalnych, albo też - zwyczajnie starając się zaskarbić względy hetmana obsyłała go informacjami o ważniejszych wydarzeniach w życiu politycznym, społecznym i towarzyskich w miejscach ich służby. Jeżeli zaś chodzi o korespondentów odgrywających ważną rolę w państwie, często sprawujących najwyższe urzędy, to należy wyróżnić kilka przypadków. Pierwszy - gdy jednocześnie byli szefami regimentów lub rotmistrzami chorągwi i w ich relacjach $z$ hetmanami mieszały się sprawy wojskowe z politycznymi i prywatnymi, często przy tym $\mathrm{w}$ jednym liście, zacierając nawet $\mathrm{w}$ ich treści stosunek zależności służbowej. Drugi przypadek to prośby o libertację dóbr, wycofanie z nich oddziałów wojskowych itp. Trzeci - listy relacjonujące przebieg działań zbrojnych, w XVIII w. znacznie rzadsze niż w stuleciach poprzednich, choć stosunkowo liczne w spuściźnie po A.M. Sieniawskim i J. Potockim. Jeżeli chodzi o tego ostatniego, to dotyczą tak wydarzeń z okresu wielkiej wojny północnej, wojny o sukcesję polską (z zastrzeżeniem, że Potocki był wtedy „tylko" regimentarzem generalnym wojska koronnego) $\mathrm{i}$ - następnie - zmagań z hajdamakami ${ }^{109}$. Czwarty wreszcie przypadek to korespondenci nie mający żadnych związków z wojskiem, ale ze względu na pełnione przez nich urzędy szczególnego znaczenia nabierały ich listy do hetmanów w sprawach wojskowych czy relacji z państwami sąsiadującymi z Rzeczpospolitą. Nawet osoby prowadzące kancelarie hetmanów nie wiedziały, jak zakwalifikować takie listy, często wpisując je do kopiariuszy z korespondencją wojskową i dyplomatyczną. Wiele takich przypadków można znaleźć w dokumentacji wojskowej Józefa Potockiego i Jana Klemensa Branickiego ${ }^{110}$. Takich problemów nie sprawiała korespondencja o charakterze służbowym z podwładnymi oraz z urzędnikami wojskowymi. Jak słusznie zauważył K. Syta „stanowiła bodaj najistotniejszy element $\mathrm{w}$ systemie dowodzenia $\mathrm{i}$ administrowania wojskiem. $\mathrm{Z}$ braku innych środków komunikacyjnych, $\mathrm{z}$ wyłączeniem osobistych kontaktów hetmanów z podwładnymi, była ona w zasadzie jedyną formą komunikacji, któ-

${ }^{108} \mathrm{~W}$ wyniku tego powstały niekiedy bardzo duże zespoły liczące po kilkaset, a nawet kilka tysięcy jednostek archiwalnych zawierających tylko listy: Sieniawskiego i Czartoryskich, BCz, 5756-5999; Radziwiłłów, AGAD, AR, dz. IV i V; J.K. Branickiego, AGAD, ARos, K, pudła 1-36; ZAB, I KH, nr 1-2451.

${ }_{109}$ AGAD, ARos, pudło 3.

${ }_{110}$ AGAD, ARos, pudło 3, AGAD, APPot, nr 127-129; PHБ, ф. 957, nr Pol. IV 282; AGAD, ARos, K, pudła 1-36. 
ra pozwalała im na: wydawanie rozkazów, sprawowanie kontroli nad wojskiem, otrzymywanie informacji dotyczących zagrożenia zewnętrznego oraz stanu poszczególnych oddziałów" "111. Częste są rozkazy dotyczące zwołania kół (generalnych, regimentarskich i najczęstszych, chorągwianych) i wysyłania pododdziałów do wykonania konkretnych zadań służbowych, które w długim okresie pokoju jak się wydaje - stanowiły dla hetmanów najbardziej widome świadectwo ich władzy nad wojskiem. Sporą ilościową grupę stanowią rozkazy i listy hetmanów związane z ruchem kadrowym w poszczególnych oddziałach - dymisje, urlopy, itp. Stosunkowo najwięcej takiej korespondencji zachowało się w spuściźnie po Janie Klemensie Branickim i Michale Kazimierzu Radziwille, a to dzięki sporządzanym w specjalnych księgach lub brulionach odpisom i regestrom wysyłanych listów hetmańskich ${ }^{112}$. Znacznie skromniejsza jest spuścizna po innych hetmanach i regimentarzach, o ile oczywiście pominąc ich listy zachowane w innych archiwach rodowych (w XVIII w. - u odbiorców), gdyż sprowadza się do kilkudziesięciu, może ponad stu listów w kopiariuszach prowadzonych w kancelarii J. Potockiego ${ }^{113}$, czy kilkunastu listów w odpisach zachowanych w papierach Adama Sieniawskiego ${ }^{114}$ lub Stanisława Poniatowskiego ${ }^{115}$. Z kolei podwładni w ten sposób mogli składać ,,powinne raporty”, informować o sytuacji militarnej, aprowizacyjnej, sanitarno-higienicznej itp. w rejonie stacjonowania, zabiegać o awanse, nagrody, urlopy lub zwolnienie ze służby czy o egzempty czasowo uwalniające z odpowiedzialności prawnej i konieczności stawiania się w sądach. Tego typu listy stanowią więcej niż 15\% zachowanej spuścizny korespondencyjnej po Branickim, a przekłada się to na ponad 300, może nawet 500 jednostek listowych ${ }^{116}$. Znacznie więcej problemów sprawia wydzielenie korespondencji wojskowej przesyłanej do M.K. Radziwiłła, gdyż włączona została do olbrzymiej spuścizny korespondencyjnej po kilkunastu pokoleniach rodu. Niewątpliwie jednak zawarta jest w ponad 100 jednostkach listowych. Podobnie prezentuje się korespondencja służbowa podwładnych z A.M. Sieniawskim ${ }^{117}$. Bardzo ciekawie przedstawia się natomiast korespondencja służbowa Rzewuskich - stosunkowo spora w przy-

${ }^{111}$ K. Syta, Dokumentacja wojskowa..., s. 57; Idem, Archiwa hetmanów koronnych..., s. 94-96.

112 AGAD, ARos, K, Supl., 4-19; AGAD, ARos, M, pudło 2 i 3; AGAD, AR, dz. VII, nr 1a, 1b, 1c, 1d, 2, 3, 3a, 3b, 3c; luźne akta nr 75 i 76.

113 AGAD, ARos, pudło 3, AGAD, APPot, nr 127-129; PHБ, ф. 957, nr Pol. IV 282. Patrz też korespondencja J. Potockiego z A. Czartoryskim, BCz, 5920.

$114 \mathrm{BCz}, 2635$.

115 AGAD, ARP, nr 365; AGAD, APPot, 127, 128, 129; AGAD, ARos, M, pudło 2 i 3.

116 AGAD, ARos, K, pudła 1-35, 51-60. Korespondencja wojskowa Branickiego też: AGAD, Braniccy z Suchej, nr 76.

117 BCz, 5760-5999; częściowo wykorzystana w monografii J. Ronikiera, Hetman Adam Sieniawski i jego regimentarze. Studium z historii mentalności szlachty polskiej 1706-1725, Kraków 1992, jak też w artykułach innych badaczy. 
padku Seweryna - kilkaset listów z lat 1774-1794118, znacznie uboższa Wacława - dwa kopiariusze korespondencji hetmańskiej oraz kilkadziesiąt listów do różnych wojskowych ${ }^{119}$ tudzież praktycznie nieistniejąca w przypadku Stanisława Mateusza. Archiwum hetmańskie Rzewuskich wzbogacają natomiast dołączone do niego akta prywatne dwóch oficerów: Samuela Brodowskiego i Andrzeja Grotowskiego, z korespondencją w sprawach regimentu pieszego $(1754-1765)^{120}$. Odrębną grupę korespondencji, w przypadku której nie ma wątpliwości, że miała ona charakter wojskowy i militarny, stanowią listy o charakterze dyrektywnym sygnowane przez władcę lub urzędnika działającego z jego upoważnienia, jak też korespondencja między hetmanami oraz odpisy listów hetmańskich kierowanych do innych dowódców wojskowych ${ }^{121}$.

\section{ZAKOŃCZENIE}

Krzysztof Syta w swojej rozprawie doktorskiej poświęconej archiwom hetmańskim sformułował tezę, powtórzoną następnie w artykule opublikowanym w 2001 r. w 13 tomie „Miscellanea Historico-Archivistica”, że archiwa „hetmanów wielkich i polnych zarówno koronnych, jak i litewskich" miały charakter prywatny i nigdy nie uzyskały charakteru publicznego, „w przeciwieństwie do archiwów wytworzonych przez pozostałe urzędy centralne I Rzeczypospolitej kanclerstwa, marszałkostwa i podskarbiostwa". Jako powody takiego stanu rzeczy podał „a) stosunkowo późne, w porównaniu z innymi urzędami centralnymi, ukonstytuowanie się urzędu hetmańskiego w hierarchii urzędów ministerialnych i dygnitarstw koronnych, b) brak szczegółowego, konkretnego sprecyzowania zakresu kompetencji i uprawnień władzy hetmańskiej, c) bardzo rozległy zakres

\footnotetext{
118 ANKr, APodh, APodh, III, pudła II i XIII

119 ANKr; Apod II, 230; APodh, III, pudło I-1/157

120 APKr, APodh I, 134-150.
}

121 Przykładowe jednostki z korespondencją między hetmanami: AGAD, APPot, 127, 128, 129 (J. Potocki z J.K. Branickim oraz hetmanami litewskimi); AGAD, AR, dz. V, nr 1334 (listy J.K. Branickiego do M.K. Radziwiłła), nr 9340 (M. Massalski do M.K. Radziwiłła), nr 12245 (J. Potocki do M.K. Radziwiłła i innych Radziwiłłów), nr 17503 VI-VIII (M.S. Wiśniowiecki do M.K. Radziwiłła); AGAD, ARos, K, pudło XIII/48 (M. Massalski do J.K. Branickiego), pudło XVII/4 (J. Potocki do J.K. Branickiego), pudło XVIII/16 (M.K. Radziwiłł do J.K. Branickiego), pudło XIX/27 (W. Rzewuski do J.K. Branickiego); AGAD, ZAB, nr 1818-1821 (M. Massalski do J.K. Branickiego), nr 2847 (J. Potocki do J.K. Branickiego), nr 2833 (M.K. Radziwiłł do J.K. Branickiego), nr 2963 (W. Rzewuski do J.K. Branickiego); ANKr, APodh, III, pudło I 1/5 (S. Rzewuski do F.K. Branickiego), 2/1 (J.K. Branicki do W. Rzewuskiego), pudło II 2/76, pudło IX 2/5-7, pudło XII 14, 15, 18 (P. Ożarowski do S. Rzewuskiego). Odpisy korespondencji innych hetmanów, „obcych” w stosunku do twórców spuścizny, AGAD, ARos, M. pudło 3; ANKr, APodh, APodh, III, nr VI/3. Do tej grupy należy zaliczyć też, stanowiące pomoc kancelaryjną, formularze uniwersałów i listów ilustrowane konkretnymi przykładami: ANKr, APodh, II, 50. 
uprawnień związanych z hetmaństwem koronnym, d) brak nadzoru nad osobami sprawującymi urząd hetmański ze strony króla, sejmu i senatu, e) duża mobilność hetmanów wynikająca $\mathrm{z}$ racji pełnienia urzędu wymagającego częstej zmiany miejsca pobytu" ${ }^{122}$. Trudno jednak z taką tezą zgodzić, gdyż w wiekach XVI-XVIII nie istniały archiwa hetmańskie jako instytucje ${ }^{123}$. W tym czasie mamy do czynienia z biurami czy kancelariami nazywanymi naprzemiennie wojskowymi i hetmańskimi, które wytwarzały i gromadziły dokumentację związaną z administrowaniem i dowodzeniem armiami kwarcianymi i komputowymi. Duża cześć tej dokumentacji powinna przechodzić przez opłacane z pieniędzy largicyjnych kancelarie wojskowe, które bez wątpienia były instytucjami publicznymi. Taki też charakter miała i wytwarzana przez nie dokumentacja wojskowa, która po zakończeniu bytu kancelaryjnego była w nich archiwizowana i następnie powinna była trafić do archiwów publicznych, gdyby takie istniały. A ponieważ ich nie było, to poza wytwarzanymi przez te kancelarie oraz przez pisarzy obu armii, a w XVIII w. także przez trybunały skarbowe, popisami wojska i innymi dokumentami rozliczającymi wojsko od strony finansowej, które stanowiły cześć archiwaliów skarbowych, praktycznie cała dokumentacja wojskowa ostatecznie dołączana była do spuścizny po zmarłym hetmanie, często rodowej. Tam w trakcie porządkowania ulegała przemieszaniu z dokumentami o charakterze bardziej osobistym. Dokumentacja wojskowa nie zatracała jednak przez to swojego publicznego charakteru, a jedynie tworzył się nieformalny z punktu widzenia prawa i praktyki biurokratycznej byt, który kolejne pokolenia archiwistów i historyków zaczęły nazywać archiwum hetmańskim. Posiada on przy tym niejednorodny charakter, co przyznaje K. Syta stwierdzając, że „za zasób archiwum hetmańskiego, rozumianego jako archiwum urzędu, przyjąć wypada wyłącznie archiwalia bezpośrednio związane ze sprawowaniem hetmaństwa, począwszy od dokumentu nominacyjnego na urząd hetmański, przez archiwalia odzwierciedlające sprawo-

${ }^{122}$ K. Syta, Dokumentacja wojskowa..., s. 51. Liczne przyczyny, dla których uważa archiwa hetmańskie za prywatne K. Syta przedstawił w: Archiwa hetmanów koronnych..., s. 66-71.

${ }^{123}$ Nie sposób też zgodzić się ze wskazanymi przez K. Sytę czynnikami, które sprawiły, że archiwa hetmańskie nie nabrały charakteru publicznego, poza pierwszym o stosunkowo późnym ukonstytuowaniem się urzędu hetmańskiego oraz bardzo rozległymi uprawnieniami z nim związanymi. Oczywiście z zastrzeżeniem, że dotyczy to na dobrą sprawę jedynie hetmaństwa wielkiego, które wszak w 1717 r. opisano prawnie określając najważniejsze kompetencje hetmana wielkiego. Należy przy tym podkreślić, że za sprawą traktatu warszawskiego i konstytucji sejmu niemego urząd hetmański stał się jedynym urzędem centralnym, który w jakiś sposób opisano prawem. O tym, że w XVIII w. hetmanom udało się do 1766 r. wyrwać z okowów prawa zadecydował brak nadzoru nad osobami dzierżącymi buławy ze strony króla, sejmu, senatu czy trybunałów, który wszakże możliwy był do wprowadzenia. Zwłaszcza, że po 1717 r. do historii przeszła duża mobilność hetmanów, którzy jeżeli zmieniali miejsce pobytu, to za sprawą czynników prywatnych lub wykonywania innych obowiązków publicznych. W osiemnastym stuleciu wręcz incydentalne były podróże hetmanów w celach służbowych, jak Józefa Potockiego jesienią 1736 r. na Ukrainę. 
wanie przez hetmanów właściwej władzy wojskowo-administracyjnej, skarbowej, sądowniczej i dyplomatycznej, łącznie z korespondencją odnoszącą się tylko i wyłącznie do spraw związanych z dzierżeniem buławy"124. Jeżeli zaś w taki sposób postrzega się archiwum urzędnika państwowego czasów Rzeczypospolitej Obojga Narodów, to nieprawdziwe jest stwierdzenie o pozostawaniu archiwów hetmańskich na niższym poziomie rozwoju niż kanclerskie, marszałkowskie czy podskarbińskie. W przypadku tych ostatnich, przechowywano w nich dokumentację, która nabierała charakteru ksiąg wiary publicznej, stanowiła sprawozdanie ze sprawowanego urzędu składane na forum sejmowym czy też była podstawą funkcjonowania systemów podatkowych i administrowania królewszczyznami. Brak w niej dokumentacji administracyjnej tych urzędów, a przede wszystkim korespondencji służbowej kanclerzy, marszałków czy podskarbich. Taki materiał źródłowy porozrzucany jest po różnych archiwach rodowych, tak jak i spuścizny hetmańskie. Dlatego nie należy dzisiaj oczekiwać, że badacz dotrze do nich w jednej instytucji archiwalnej czy bibliotecznej, a tym samym - w jednym zespole. W przypadku spuścizn hetmańskich wyjątek stanowi Archiwum Podhoreckie Rzewuskich, choć bliższe zapoznanie się z jego zasobami wskazuje na liczne braki. Dokumentacja wojskowa Jana Klemensa Branickiego - wytworzona przez jego „biura” wojskowe i obsługujące korespondencję zagraniczną - rozdzielona została na trzy części, które tylko dzięki szczęśliwemu zbiegowi okoliczności znajdują się obecnie w jednej instytucji archiwalnej, choć w trzech zespołach. Z kolei dokumentacji hetmanów z domu Radziwiłłów należy poszukiwać w kilku archiwach i bibliotekach na terenie Polski, Białorusi, Litwy i Rosji. W przypadku pozostałych osiemnastowiecznych hetmanów - spuścizna o charakterze wojskowym zachowała się co najwyżej w formie szczątkowej i rozproszonej, a jej ewentualne zebranie $\mathrm{w}$ tzw. inwentarzu idealnym wymagałoby olbrzymiego nakładu pracy, niewspółmiernego do osiągniętych rezultatów badawczych.

Dokumentacji wojskowej niezbędnej do odtworzenia dziejów armii i wojskowości polsko-litewskiej w XVIII w. należy poszukiwać w wielu archiwach i bibliotekach krajowych oraz poza granicami Polski. W nich też od XIX w. badacze zajmujący się dziejami Rzeczypospolitej Obojga Narodów, i to nie tylko jej aspektami wojskowymi, poszukują podstawowych, a przy tym rzetelnych źródeł informacji. Nic w tym dziwnego, gdyż tworząca zasób archiwaliów hetmańskich dokumentacja wojskowa miała w XVIII w. charakter publiczny, co przyznawali sami hetmani. Znaczenie dokumentacji wytwarzanej i przechodzącej przez kancelarię osób dzierżących buławy niewątpliwe znacząco zmalało w Koronie w 1764 r., a w Wielkim Księstwie Litewskim - w 1766 r., gdy powołane zostały komisje wojskowe, organy władzy o charakterze kolegialnym, którymi przewod-

${ }^{124}$ K. Syta, Dokumentacja wojskowa..., s. 51. 
niczyli hetmani. Dokumentacja wojskowa, która do tej pory przechodziła przez kancelarie wojskowe działające przy boku hetmańskim, zaczęła być wytwarzana i gromadzona w kancelariach najpierw komisji wojskowej, następnie Departamentu Wojskowego Rady Nieustającej i w końcu Komisji Wojskowej przy Straży Praw - instytucji, co do których nie ma wątpliwości, że były publiczne. Co symptomatyczne, hetmani skwapliwie przejmowali pieczę nad tą kancelarią, gdy tylko pojawiały się możliwości odzyskania dawnych kompetencji: zarówno w latach 1774-1776, jak i pod rządami konfederacji targowickiej. Dowodzi tego zachowana spuścizna archiwalna po Sewerynie Rzewuskim. Potwierdza ona też i to, że nie sposób mówić o archiwach hetmańskich, lecz - o mających publiczny charakter archiwaliach hetmańskich, które w XVIII w. za sprawą różnych czynników znalazły się w archiwach rodowych, a obecnie rozproszone są w zasobach dawnych archiwów rodowych, a te w zespołach różnych archiwów i bibliotek publicznych na terenie Polski i poza jej granicami.

\title{
THE PEN IN THE SERVICE OF THE BULAVA. PORTRAYAL OF HETMAN CHANCELLERIES AND ARCHIVES IN THE $18^{\mathrm{TH}}$ CENTURY
}

\begin{abstract}
The article presents the documents issued by the military chancelleries operating by the side of the hetmans of the Polish-Lithuanian Commonwealth in the $18^{\text {th }}$ century against the backdrop of the scope of authority of the hetman office. The beginning of the century was the time of the greatest increase of power of this office in its entire history. This process occurred in an informal manner. Moreover, it was accompanied by numerous examples of abuse of power by the leaders of the Polish and Lithuanian armies. As a result, provisions were introduced in order to limit the power of the hetmans in the constitution which were approved by the Sejm in 1717 as well as in the Treaty of Warsaw. However, the restrictions were quite limited in scope and the hetmans continued to enjoy extensive authority. It allowed them to hold the entirety of the administrative and judiciary power over the military. The hetmans retained it until the mid-1760s and the military documents issued by the chancellery operating by the hetman office attest to that fact. The article examines this documentation which undoubtedly was of public nature. The first group includes documents and files pertaining to the administrative power of the hetmans: rules and regulations issued or approved by them, mostly organizational in nature, hetman orders as well as reports sent in by the military forces regarding the number of soldiers, equipment or personnel shifts, etc. Another group contains financial documentation pertaining to the maintenance of both armies (also including the forces called hetman's troops) and of the hetman office itself. The third group is composed of files and correspondence related to the diplomatic activity of the hetmans. The fourth set holds whole documentation connected with the disciplinary authority and judiciary power of the hetmans. And the final fifth set consists of the official correspondence between the hetmans and their subordinates as well
\end{abstract}


as with the king, the ministers and the more important state officials. There is an archival legacy rich in source materials retained after the following hetmans: Adam Mikołaj Sieniawski, Jan Klemens Branicki, Michał Kazimierz Radziwiłł as well as three representatives of the Rzewuski family who held the office in the $18^{\text {th }}$ century. These sources enable one to come to the conclusion that the military documentation was issued as public and, as such, it was subject to the processes of creating files and archives in the hetman chancelleries. It is likely that during a hetman's lifetime the military documentation was stored separately from the remaining documents and files which were public in character. And more importantly, the military documents were not kept together with legal, estate, accounting as well as economic papers. Following a hetman's passing, it was customary for their heirs to discontinue taking special care of the military documentation. Instead, they treated it as a private component of the estate and it was included with the remaining files belonging to the deceased. Consequently, they were subjected to a preliminary archival processing. As a result, the so-called hetman archives began to be viewed as private documents even though they were issued as public ones. This can be proved by the change in the archival processing occurring in the case of the military documentation in the second half of the 1760s. At the time, the hetmans lost their actual power over the armies of the Commonwealth to the Crown Military Commission and to the Lithuanian Military Commission. The entirety of the military documentation was thenceforth issued and initially collected in the chancelleries of the military commission. Subsequently, it was transferred to the Military Department of the Permanent Council and then, finally, to the Military Commission at the Guardians of the Laws. These institutions were, without a shadow of a doubt, public.

\section{STYLOS AU SERVICE DE BOULAVA. DES CHANCELLERIES D'HETMAN ET DES ARCHIVES AU XVIIIE SIECLE}

\section{Resumé}

L'article présente la documentation produite par les chancelleries militaires fonctionnant auprès des hetmans de la République des Deux Nations (Pologne-Lituanie) au XVIII ${ }^{\mathrm{e}}$ siècle, dans le contexte des compétences légales des hetmans. Au début de ce siècle, le renforcement du pouvoir des hetmans, le plus grand tout au long de l'histoire de cette fonction, a au lieu. Ce phénomène s'est produit de manière informelle et il était en outre accompagné de nombreux abus de la part des personnes qui commandaient les armées polonaises et lituaniennes. Cela aboutit à l'adoption par la Diète de plusieurs actes législatifs et en particulier du traité de Varsovie de 1717 contenant les dispositions qui limitaient le pouvoir des hetmans. Cependant, ces limitations se sont avérées peu efficaces et les hetmans disposaient toujours de larges compétences qui leur donnaient la possibilité d'exercer le plein pouvoir administratif et judiciaire sur l'armée. Comme le prouve la documentation militaire produite par les chancelleries des hetmans, ils l'ont conservée jusqu'au milieu des années 60 du XVIII ${ }^{\text {e }}$ siècle.

Notre article traite de cette documentation qui, sans aucun doute, était publique. Elle a été classée en cinq groupes. Le premier groupe comprend les documents et les dossiers 
liés aux autorités administratives des hetmans: des règlements émis ou approuvés par eux, principalement en matière organisationnelle, des ordres de l'hetman, des rapports sur les effectifs des unités militaires, leur équipement ou le mouvement du personnel au sein de l'armé, etc. Le deuxième groupe contient la documentation relative au financement de ces deux armées et du cabinet de l'hetman. Le troisième groupe comprend les dossiers et la correspondance liée à l'activité diplomatique des hetmans. Le quatrième - contient toute documentation relative aux autorités disciplinaires et judiciaires des hetmans, et le cinquième - toute correspondance commerciale menée par les hetmans avec leurs subordonnés, mais aussi avec le roi, les ministres et les hauts fonctionnaires de l'État.

Le patrimoine archivistique des hetmans : Adam Mikołaj Sieniawski, Jan Klemens Branicki, Michał Kazimierz Radziwiłł ainsi que trois représentants de la famille Rzewuski qui exerçaient leur fonctions au XVIII ${ }^{e}$ siècle, indique que la documentation militaire a été créée en tant que publique et a été soumise à des processus d'archivage réalisés par les chancelleries d'hetman. Probablement, pendant la vie des hetmans, la documentation militaire était archivée séparément des autres documents et dossiers à caractère public, et en particulier, des documents juridiques et patrimoniaux ainsi que comptables et commerciaux. Cependant, après la mort d'un hetman, leurs héritiers ont généralement cessé de traiter la documentation militaire avec un soin particulier et la traitaient comme une partie privée de l'héritage. Ils ont joint cette documentation à l'ensemble des biens du défunt et l'ont fait l'objet d'un processus d'archivage préliminaire. En conséquence, les soi-disant archives d'hetman ont commencé à être traitées comme privées, bien qu'elles aient été créées comme publiques. La preuve est la modification du processus d'archivage de la documentation militaire qui a eu lieu au milieu des années $60 \mathrm{du}$ XVIII ${ }^{e}$ siècle, lorsque les hetmans ont perdu le pouvoir réel sur les armées de la République au profit de la Commission militaire polonaise et de la Commission militaire lituanienne. Au début, tous les documents militaires ont commencé à être produits et rassemblés dans les chancelleries de la Commission militaire, ensuite dans le Département militaire du Conseil permanent et enfin dans la Commission militaire agissant auprès de la Garde des droits - les institutions qui, sans aucun doute, étaient publiques. 